\title{
7. PLIOCENE AND QUATERNARY MUD TURBIDITES IN THE GULF OF CALIFORNIA: SEDIMENTOLOGY, MASS PHYSICAL PROPERTIES AND SIGNIFICANCE ${ }^{1}$
}

\author{
Gerhard Einsele, Geologisches Institut der Universität Tübingen, Tübingen, Federal Republic of Germany \\ and \\ Kerry Kelts, Eidgenössische Technische Hochschule, Geologisches Institut, Zürich, Switzerland
}

\begin{abstract}
A large proportion of the Pliocene and Quaternary basin fill in the Gulf of California is composed of relatively finegrained mud turbidites which have sedimentary structures that are more subtle than those of sandy turbidites in flysch deposits. Basal contacts are sharp, sometimes accompanied by thin, laminated, muddy sands; the silty body commonly appears massive, and the tops consist of a thin zone with faint burrow traces. The composition, physical properties, textures, and sorting of biogenic components document graded intervals. The composition of these beds reflects source areas ranging from thick, hemipelagic diatom ooze blankets to muddy delta foreslopes. In the Guaymas Basin, these sources lead to two end member types: I, Pale olive to moderate olive brown, nannofossil-bearing diatom ooze to mud, $\mathrm{cm}$-to-decimeter thick; and II, dark to medium olive gray to medium gray, terrigenous, silt-rich muds, from decimeters to over 12 meters thick, with low percentages of biogenic components. Type I is probably redeposited from intrabasinal bathyal slope regions, whereas Type II represents more distal transport from outer, muddy deltaic slopes. The tops of some Type I beds are pure diatom ooze layers, the result of hydraulic sorting. In core sections recovered undisturbed by the hydraulic piston corer, mass physical property gradients for turbidites (water content, wet-bulk density, porosity, shear strength, and shrinkage) are clearly distinguished from the host sediment by their higher bulk densities and lower porosities. Basal parts of turbidites have the lowest porosities but are highly permeable and so function as conduits for pore fluids and are sites for early silica and carbonate diagenesis. This type of mud turbidite facies, commonly with intercalated mud flows, is found in the internal tectonic zones of many orogenes.
\end{abstract}

\section{INTRODUCTION}

On first examination, almost all cores from Leg 64 seem to consist of a monotonous series of structureless, drab olive hemipelagic sediments. Much of this impression is compounded by extensive drilling disturbance, in some cases accompanied by frothing of the sediment in the core tubes because of exsolving gas. Where there were glimpses of sections undisturbed because of compaction or intrusion-related lithification-particularly in sections produced by the hydraulic piston corer at Site 481 -it became obvious that most of the basinal sediments were redeposited and organized into muddy turbidite beds with varying secondary characteristics. The Gulf of California has often been likened to ancient flysch basins (for instance, by van Andel, 1964) and we were mildly surprised at the disproportionate amounts of redeposited muds rather than graded sands with Bouma sequences. Coarser clastic components are apparently efficiently trapped in the numerous, structurally controlled slope basins. Because of the relative importance of hemipelagic sediment in slopes and basins of ancient orogenes and because the characteristics of turbidite sedimentation in young, narrow ocean basins are poorly documented (see Thiede, 1978; Pilkey et al., 1980; Ricci-Lucchi and Valmori, 1980; Hsü et al., 1980) the purpose of this paper is to summarize the observations from Leg 64 and present, for the first time, a reli-

${ }^{1}$ Curray, J. R., Moore, D. G., et al., Init. Repts. DSDP, 64: Washington (U.S. Govt. Printing Agency). able set of mass physical property data for relatively unconsolidated turbidite sequences from such deep settings. The role of mud turbidites in the deep sea along continental margins has only recently come under closer scrutiny (for instance, Rupke and Stanley, 1974; Hesse, 1975; Piper, 1978; Stow and Bowen, 1980; Kelts and Arthur, 1981; Malouta et al., 1981; and Stanley and Maldonado, 1981). Our goal is to present some parameters which provide constraints on depositional models in such basins and to discuss briefly some of the significance and implications of such deposits.

Hemipelagic, as used in this chapter, refers in a broad fashion to fine-grained, deep-sea sediment in which more than $25 \%$ of the nonclay fraction is derived from terrigenous sources. It can also be used to depict the common site of deposition along continental margins and their adjacent basin plains. As such, deposits may either have settled out as a blanket from the neritic zone or been emplaced by lateral mass transport mechanisms along the bottom. A term with inherent ambiguities, hemipelagic can also include turbiditic muds.

\section{LEG 64 SITES IN THE GULF OF CALIFORNIA}

The site chapters (this volume, Pt. 1) provide details of the individual hole results, locations, recovery, and stratigraphy. In this chapter we focus on the best examples of relatively unconsolidated turbidites from diatomaceous oozes in various parts of the basinal settings found at the mouth of the Gulf along the Baja continental perimeter and in the Guaymas Basin (Fig. 1). We emphasize the macroscopic characteristics, composition, and physical properties of the HPC-cored Hole 481, 


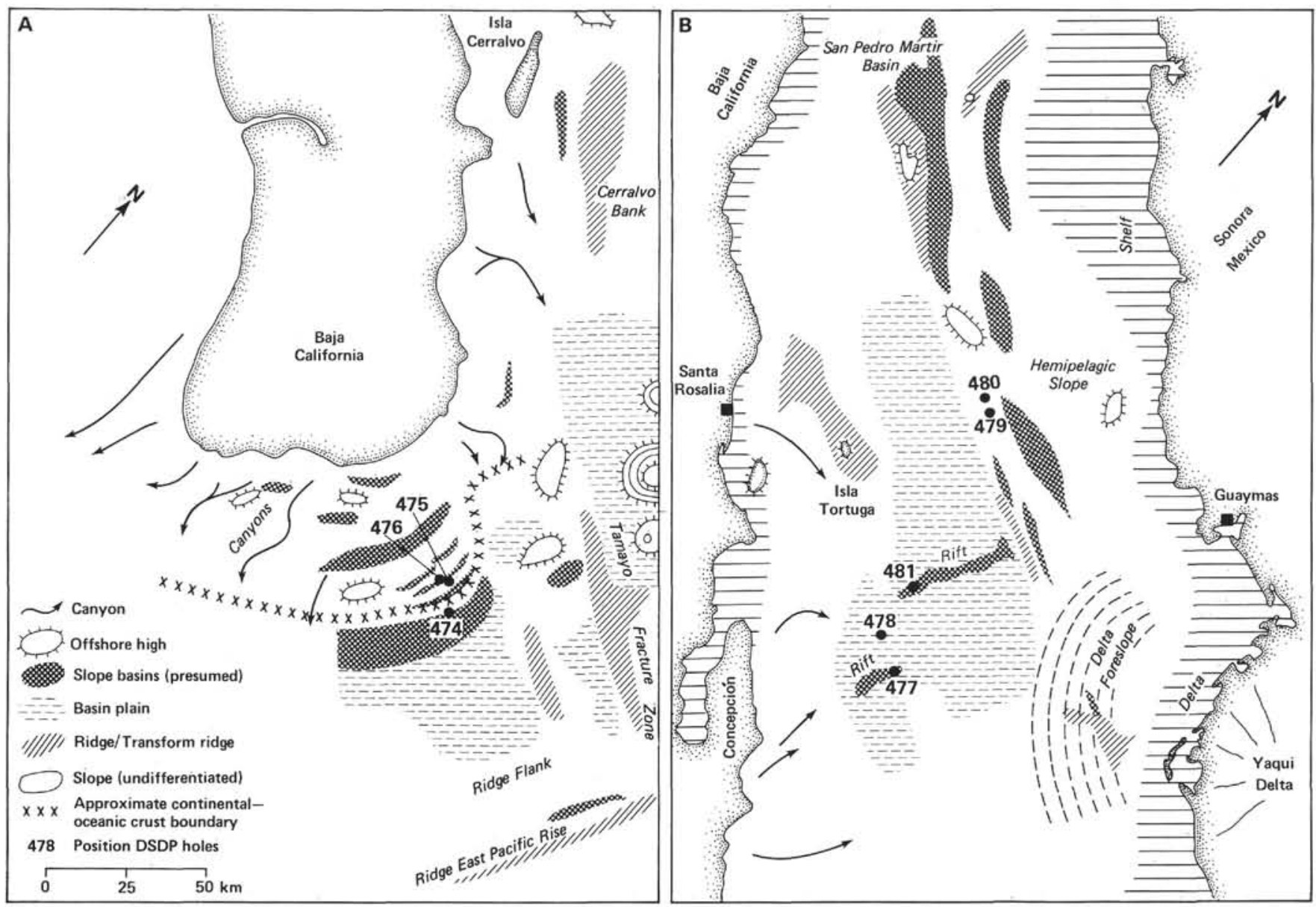

Figure 1. Generalized morphological features of the Leg 64 areas. A. Perimeter and slope basins of the southern tip of Baja California (Sites 474 , 475, and 476). B. The Guaymas Basin and Slope, central Gulf of California (Sites 477, 478, and 481: Sites 479 and 480 ).

where the top 54 meters of soft Holocene to late Pleistocene redeposited muds were recovered undisturbed.

The morphologic setting is important for the distribution of turbidite sediments. The Gulf of California is about $1000 \mathrm{~km}$ long and $100-200 \mathrm{~km}$ wide. It is a young ocean basin with passive margins (Larsen et al., 1968; Moore and Buffington, 1968; Karig and Jensky, 1972; Moore, 1973; Rusnak et al., 1964), divided into a complex series of linked basins, which are successively deeper from about 800 meters in the north to 4000 meters at the mouth (Rusnak et al., 1964; Bischoff and Niemitz, 1980).

Site 474 sampled a perimeter basin plain sandwiched between the juncture of subsided continental crust and the flanks of the youthful spreading center of the East Pacific Rise (Fig. 1A). Nearby slopes include a series of slope basins which trap hemipelagic deposits. Large submarine canyons along the eastern margin of the Baja Peninsula funnel sediment into a broad north-south channel with Site 474 at the opening. The perimeter basin is at present part of the skirt of a low-angle rise, but seismic records show it to contain the thickest sediment pile. It wedges southward toward the present geomorphic center, which has apparently migrated southward with the ridge. Perched basins containing pelagic oozes also occur along the Tamayo Fracture Zone ridge.
The history of Site 474, as read from the turbidite sequence, shows that it evolved slowly during the Pliocene from a locus for large and sandy beds to finer-grained mud turbidites, perhaps more consistent with a basinrise position. Nearby, Sites 475 and 476 are upslope on continental crust, in one of several shallow outer slope basins which are mainly catchment areas for slope overspill hemipelagics.

In the Guaymas Basin region, the situation is somewhat different. The flat basin plain is relatively small, with aprons that are initially low-angle. The center is transversely cut by the young northern and southern semigraben rifts (Fig. 1B). The largest geographic area is occupied by hemipelagic slopes although these include several elongate, perched, slope basins, some filled with trapped detritus. Very steep slopes (greater than $10^{\circ}$ ) are found near transforms, on rift walls, and along volcanic ridges.

The Yaqui River has developed a large deltaic complex, suggesting that it has existed for a very long time or that it was more actively transporting sediment at times in the past. Much of the coarse delta detritus was trapped along the margins, behind a transform ridge, until the foreslope spilled over into the basin (Moore, 1973). The deepest basin includes two young rift troughs, approximately 100 meters deep and $1-2 \mathrm{~km}$ wide. 
Sedimentation along the broad hemipelagic slope area is dominated by prolific diatom growth. Oozes are grouped in either laminated or nonlaminated facies, reflecting, respectively, a low level of oxygen and lack of benthic fauna and the existence of a burrowing infauna. A few scattered volcanic pinnacles and hills occur within the basinal areas and may provide local sources for volcanogenic components, hyaloclastites, or hydrothermal products. Along the western margin, slopes are steeper, no major rivers empty into the basin, and shelf storage space is limited. Here again, although the topography is broken by a series of fault-bounded steps running parallel to the present coastline (Bischoff and Henyey, 1974), evidence for submarine canyons suggests more active transport in the recent past.

Sites 477 and 481 are located within the narrow, shallow, oblique central rifts of the Guaymas Basin plain. Site 478 is located north of the southern rift in a broader basin plain region, but is also in the extension of a leveed submarine canyon which heads along the steep Baja coast. Low oxygen levels and the persistence of turbid clouds in deep basinal areas suggest low ambient current levels (Rusnak et al., 1964; Lonsdale and Lawver, 1980).

Sites 479 and 480 (Fig. 1B) along the outer slope margin recovered samples from a blanket of mostly muddy diatomaceous ooze with seasonal, high accumulation rates (greater than $500 \mathrm{~m} / 10^{6} \mathrm{y}$.), but little of this derived from redeposition. The very active tectonic setting, steep slopes, and high accumulation rates of terrigenous and biogenous oozes combine to produce mass flows and probably erosion in this region. Submersible observations (Lonsdale and Lawver, 1980) show freestanding scarps of thick-bedded Holocene muds along the intrarift walls. Such young tectonic scarps may also lead to further localized mud flows.

\section{METHODS}

Because of intense core disturbances, the mass physical properties of young, unconsolidated sand and mud turbidites have rarely been measured. Keller and Lambert (1972) report values for piston cores from the Mediterranean Sea. More information on these properties is needed because turbidite lithologies play an important role in the drainage of pore waters from compacting sediments.

For this study, cores with least disturbance were selected and physical properties compared with the visual core descriptions. Some of the sediments in the Guaymas Basin show signs of incipient lithification, partly in conjunction with high heat-flow gradients (Einsele et al., 1980). These were examined in order to follow aspects of the initial stages of differential induration as they are reflected in the physical property gradients. Density, water content, porosity, shrinkage, sonic velocity, GRAPE bulk density, grain densities, and shear strength were measured aboard ship on fresh core halves, according to standard procedures (Einsele, this volume, Pt. 2). In spite of the inherent inaccuracies of visual estimates, smear slide estimates of composition provided useful comparative information. Semiquantitative estimates of composition were also made by X-ray diffraction. Calcium carbonate and total carbon data are based on both the standard Carbonate Bomb and shore-based LECO Ignition methods (Simoneit and Bode, this volume, Part 2). Grain sizes were measured with ultrasonic microsieves and a HIACE particle analyzer. Downhole logging results for bulk density, resistivity, and hole size provided useful guides to recognizing large mass flow units (see site chapters, this volume, Pt. 1).

\section{SEDIMENTOLOGY}

\section{Characteristics of Single Beds}

A detailed stratigraphy of part of HPC Hole 481 best illustrates the variety of bed types in a sequence (Fig. 2). More than $70 \%$ of the recovered section appears to be resedimented, mostly as faintly graded beds. One muddy mass flow unit exhibiting convolute folds occurs from Section 481-8-1 to 8-2. Turbidites are either predominantly biogenous or predominantly terrigenous mud types; the latter are generally thicker. The thickest bed consists of graded, muddy, sandy silt from Cores 481-10 through 481-11; this appears to be only the top part of a turbidite estimated to be over 12 meters thick.

Criteria used to distinguish the approximately $30 \%$ of host sediment intercalated with turbidite beds include light/dark mm-laminated couplets, a generally lighter color, patchy burrows, and occasional deep water mollusk shells. If one assumes that the general pelagic rain accumulates at the same rate as along the outer hemipelagic slopes (approximately $500 \mathrm{~m} / 10^{6} \mathrm{y}$.), then minimum rates of accumulation on the basin floor exceed $1650 \mathrm{~m} / 10^{6} \mathrm{y}$., if the thicknesses of visibly recognized mud turbidites are added. This assumption seems warranted because the laminated couplets encountered in

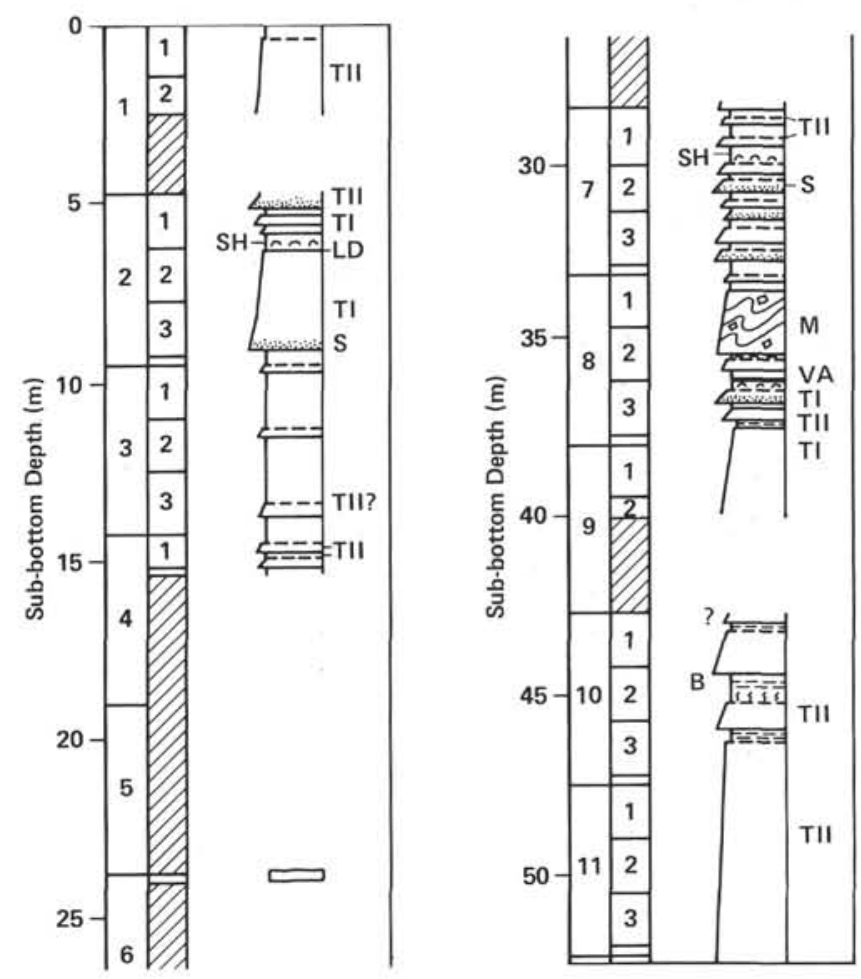

Figure 2. Detailed Late Quaternary stratigraphy of part of HPC Hole 481 , showing distribution of graded beds, cores, and recovery. Type I, olive drab graded muds, rich in biogenous components, mostly diatoms; Type II, medium gray graded muds with mainly terrigenous components; $\mathrm{M}$, small mass flow with convolute folds; VA, thin vitric ash, altered; SH, mollusk shell hash; B, burrow traces; $\mathrm{S}$, concentration of sand. 
the deep basin are about the same thickness as varvelike couplets in Hole 480 (see site chapter, this volume, Pt. 1). The composition of the host sediment of the basins is similar to the turbidites-both are rich in diatom frustules, silt, and terrigenous clay with some nannofossils $(3-13 \%)$. Host sediments generally appear to contain slightly more organic carbon (Simoneit and Bode, this volume, Pt. 2).

For the internal structures of turbidite beds of varying thickness and composition encountered in the Gulf region, we follow the terminology of Piper (1978), which expands upon the Bouma (1962) sequence by emphasizing the role of laminated, graded, and ungraded mud subdivisions in Bouma's E zone (Fig. 3). Zone F denotes a hemipelagic mud sediment which is commonly difficult to recognize separately from the redeposited beds. In most of the beds we described, the E-3 division was rare, as some parameter commonly shows evidence of grading. This may be because of the generally low oxygen levels and rapid sedimentation in the basin, which result in concomitantly low populations of burrowing organisms that would homogenize lutite tops.

From coarse to fine-grained lithologies we recognize 5 general bed types (some examples are given in Plate 1): (a) thin, well-sorted sands, (b) sand turbidites, (c) a thin, graded, coarse, sandy basal unit with a massive body of silt, (d) thick beds with a poorly sorted, silty sand base, some parallel laminations, and a massive clayey silt-rich body, and (e) thick to thin fine-grained mud turbidites with dominantly E-2 division structures and some rare clay clasts. A few winnowed, well-sorted, massive sand layers were encountered at Sites 475,476 , and 479 in

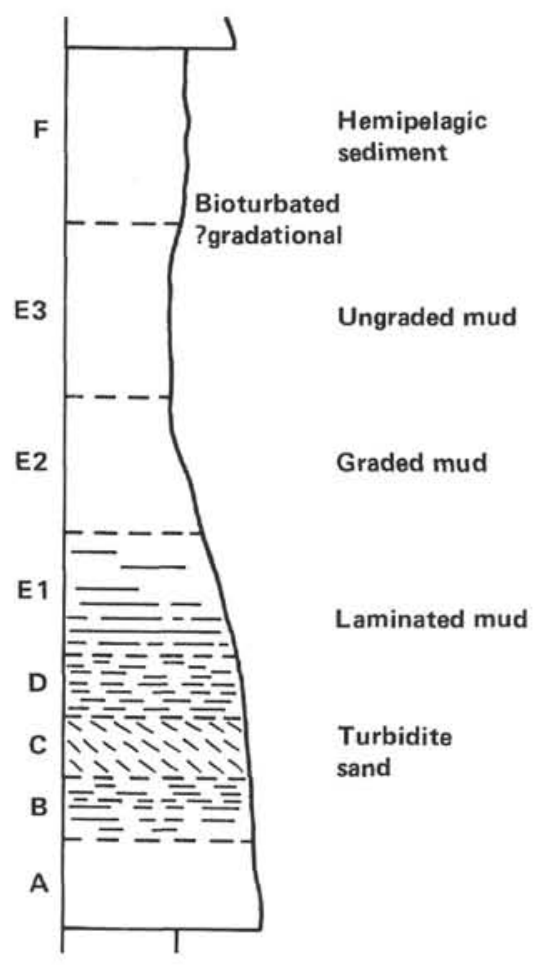

Figure 3. Sedimentary structure divisions in mud turbidite beds (after Bouma, 1962, modified by Piper, 1978). outer slope basin and rise settings, and graded sands with basal Bouma-structure sequences were encountered near the base of Hole 474 along the perimeter basin. Both types are relatively rare in Leg 64 cores. Beds with a thin, graded, sandy base and massive silt body are common. They display a thin Bouma A, B, or C layer and a laminated to homogeneous silty portion with a thick, faintly graded mud division (E-2). According to Piper (1978), mud lumps occur in all subdivisions from A through E-3, but plant debris is commonly more concentrated in E-3. We also observed a similar distribution of small mud lumps and dark brown to black wood fragments. Many beds display only E-type structures, although thicknesses may approach several meters. The E-2 type beds are most abundant. Commonly, near the top of an E-2 bed, the color of the homogeneous mud changes gradually from dark olive gray to a lighter hue because of compositional grading.

In Hole 477A, we recovered a few sand to mud core fragments which were lithified by a high-temperature hydrothermal regime. The alteration accentuated basal sedimentary structure that we did not observe in unconsolidated samples. These include scour, parallel lamination, cross-laminations, small-scale convolute folds, load casts, and one example of a basal traction layer (Fig. 4). Within this limited suite, the evidence suggests a possible pulsating mode for some turbidity current transport (Lambert, et al., 1976). Unfortunately, because of poor recovery and uncertainty about the stratigraphic position of these sediments, little can be learned of their overall importance in the basinal sedimentation.

\section{Texture}

In contrast to Piper (1978), who was able to separate graded from ungraded mud sections by size analysis, we did not find mud turbidites without some form of grading. In macroscopically massive turbiditic muds, the fine silt content decreases and clay increases, although the percentage of silt rarely drops to less than $20-30 \%$. In addition to the results of smear slide size estimates, we integrated pipette results from Gutierrez-Estrada (this volume, Pt. 2) for selected turbidite samples (Figs. 5AC). Several beds were further examined, using ultrasonic sieves, at the Geological Institute of the University of Tübingen. Pipette results for single beds are summarized in Figure 6 for sand $(>63 \mu \mathrm{m})$, silt, and clay $(<4$ $\mu \mathrm{m})$ fractions. These are organized according to bed thickness, but the data suggest that there is no clear correlation between bed thickness and sand content. Most commonly, silt dominates all but the basal part of some beds. Clay content rarely exceeds the silt fraction. In a few beds (e.g., Sections 474A-6-1-2 and 474A-13-3-4), the basal portions seem richer in the clay fraction than sections above. This is interpreted as the incorporation of fines from the substrate into the basal part of a turbidite (McCave, 1979). One case where clay decreases in the upper portion of a bed (Cores 481A-5-6) may result from the superposition of two or more turbidites without intercalated host muds. An increase of sand sizes toward the tops of several other beds reflects the presence of large diatoms or other biogenic components which 

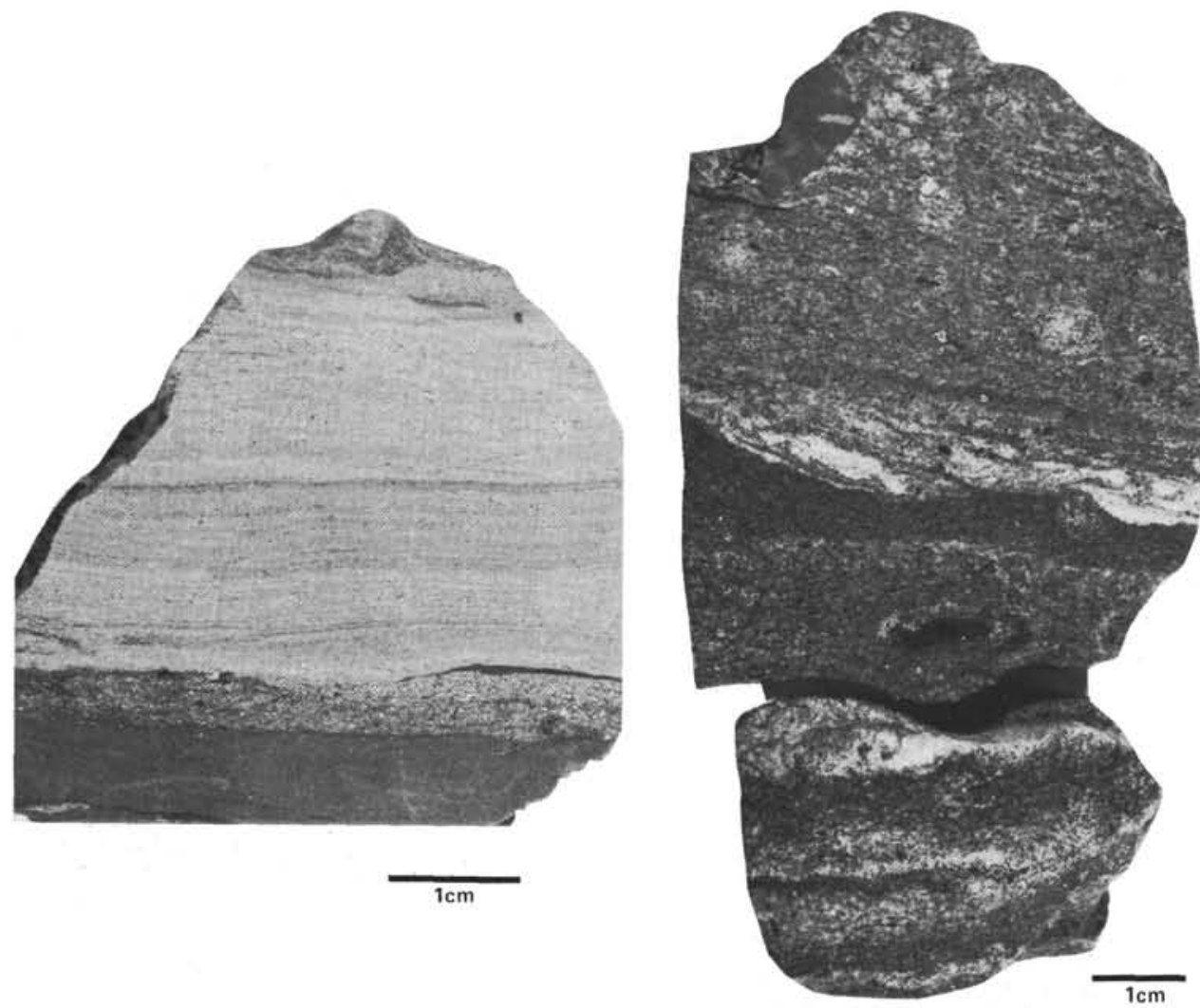

Figure 4. Sample 477A-1,CC. Two examples of basal portions of sandy turbidites showing sedimentary structures which have been enhanced by extensive hydrothermal lithification. These include current lamination, flow banding, small-scale load casts, phacoidal slip, carbon flakes, and scattered mud clasts; see site chapter for Site 477 (Guaymas Basin), this volume, Pt. 1.

have a hydraulically much smaller equivalent grain size. This may also apply to most of the host sediment, which contains up to $4 \%$ sand sizes. Most of the Guaymas Basin host sediment is classified as silty clay, whereas in the sites at the tip of Baja, clayey silts are dominant. Variations in size composition abound as the result of difficulties in recognizing unit boundaries and of reworking by burrowing organisms. Textural patterns from ultrasonic sieving methods are not directly comparable to settling results (see Fig. 7). Fractions from selected turbidite beds were sieved from 100 to $5 \mu \mathrm{m}$ and the fraction less than $2 \mu \mathrm{m}$ was filtered with a pore-membrane. Small wet samples were initially treated with $\mathrm{H}_{2} \mathrm{O}_{2}$ but not boiled. Several size fractions were checked by microscopy, which showed residual aggregates of clay and diatoms (fecal pellets?), which reach significant proportions in some samples and are counted in the sand fraction. The grain size distributions (Fig. 7) of all samples show two or three distinct modes, one in clay size and another in coarse silt to sand. Coarser modes are caused by terrigenous components, microfossil tests, and aggregates. Components in the 4 to $20 \mu \mathrm{m}$ range are lacking. Grading within beds is commonly the result of an upward shift to finer silt fractions (Figure 7A, B, C), a phenomenon which has also been discussed by Piper (1978) and McCave (1979). This pattern can be formed in graded beds by gradual increase of the fine-grained mode, which is initially present in basal layers (Fig. 7D).
Shifts in modes are less decipherable where the coarse mode comprises mainly diatom frustules and fecal pellets (Fig. 7E). Host muds show similar but less pronounced modal distributions, a fact that indicates the close relationship between host and turbidite mud.

\section{An Explanation of Thick Diatom Ooze Layers}

In several undisturbed core sections of the Guaymas Basin, intermittent centimeter-to-decimeter, pale olive layers of almost pure diatom ooze stand out clearly against the dominant dark olive brown muds. The pale layers appear similar to the pale member of the varvelike couplets cored at the Guaymas Slope Site 480, and they were initially attributed to long-term diatom blooms. They have considerable lateral extent, as is clear from submersible photographs of outcrops along the inner rift walls (Lonsdale and Lawver, 1980). In one case from Core 481-2 (Plate 2), the top part of such a bed is characterized by a diffuse redox boundary and the preservation of unstable iron monosulfides. The presence of these indicates extremely rapid burial with high organic content such as might occur from turbidity current deposition. This interpretation is supported by evidence of gradational lower boundaries and sharp upper boundaries. Pelagic processes involving long-term upwelling and diatom blooms are a possible alternative explanation in that case but we would expect to find beds of the same thickness along marginal slopes, whereas 
A
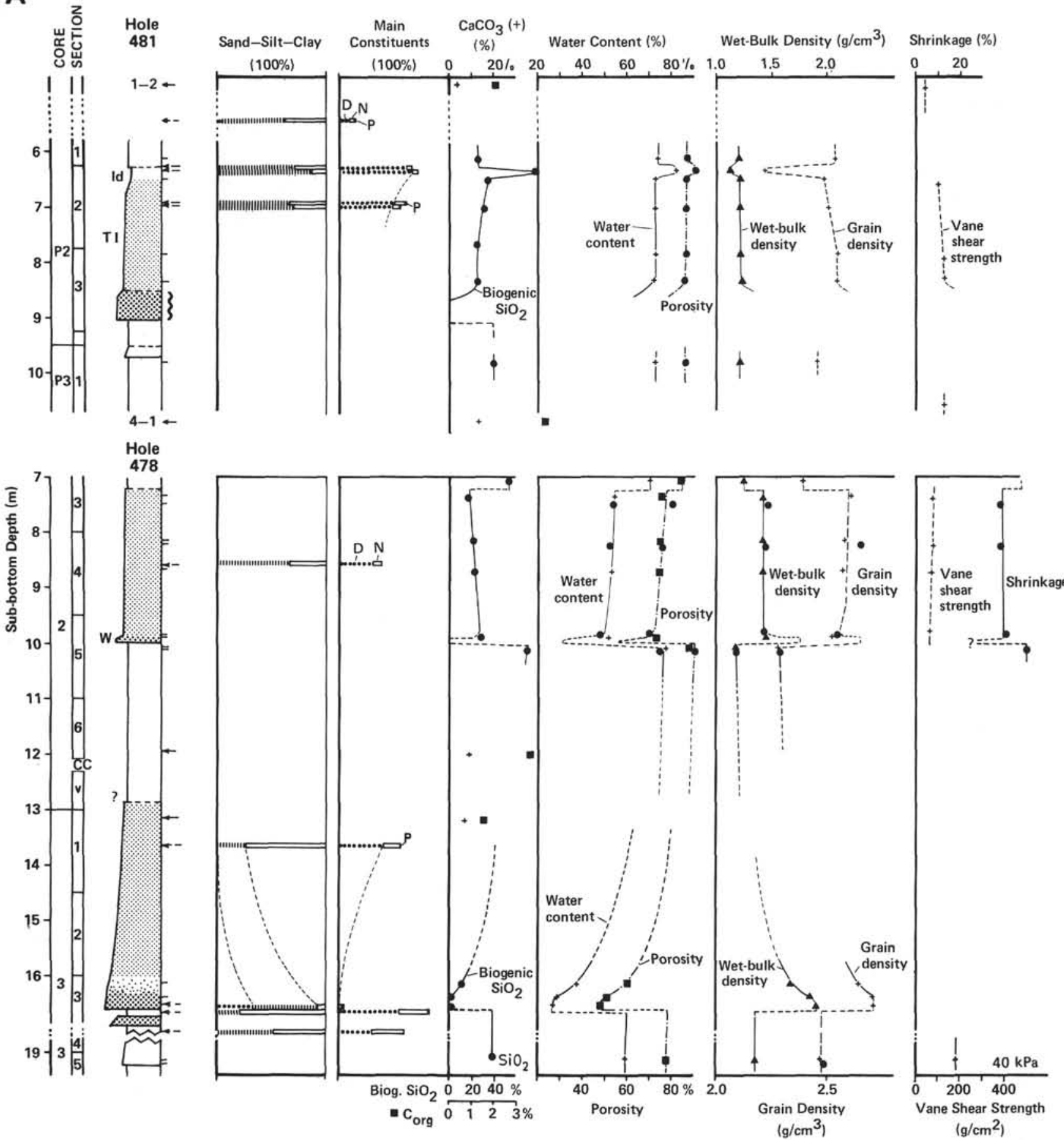

Figure 5. Physical properties, texture, composition, and lithology of selected core sections containing mud turbidites, grouped in the figures according to depth of burial. Sand-silt-clay data are from shipboard smear slides. Abbreviations: b, bioturbated; cem, cemented; d, dark; f, fine; l, light; s, sand; sh, mollusk shell debris; v, volcanic; w, washed section; D, diatoms; F, foraminifers; N, calcareous nannofossils; P, pyrite; WF, wood fragments; Q+CM, quartz, feldspar, and clay minerals. A. Upper burial ranges, from 6 to 19 meters sub-bottom, including HPC Site 481 in the Guaymas Basin rift trough and Site 478 near the basin plain edge and a fan levee. B. Medium burial ranges, from 36 to 66 meters sub-bottom, from Sites 478 and 481. C. Deeper burial ranges, from 129 to 366 meters sub-bottom, including beds from outer slope basin Site 475, Guaymas basin Site 478, and a sandy layer with carbonate cement from slope margin Site 479. 
B
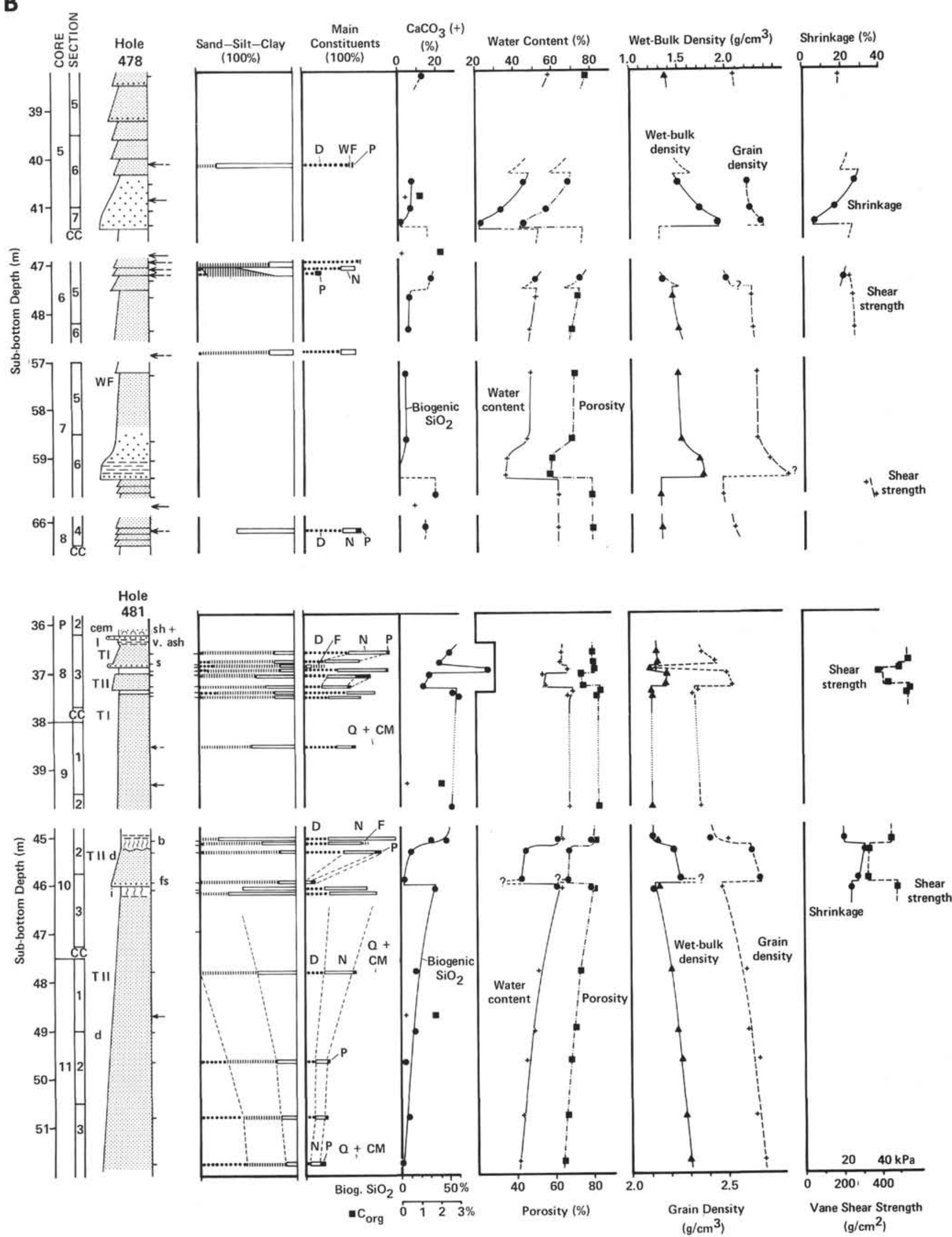

Figure 5. (Continued). 


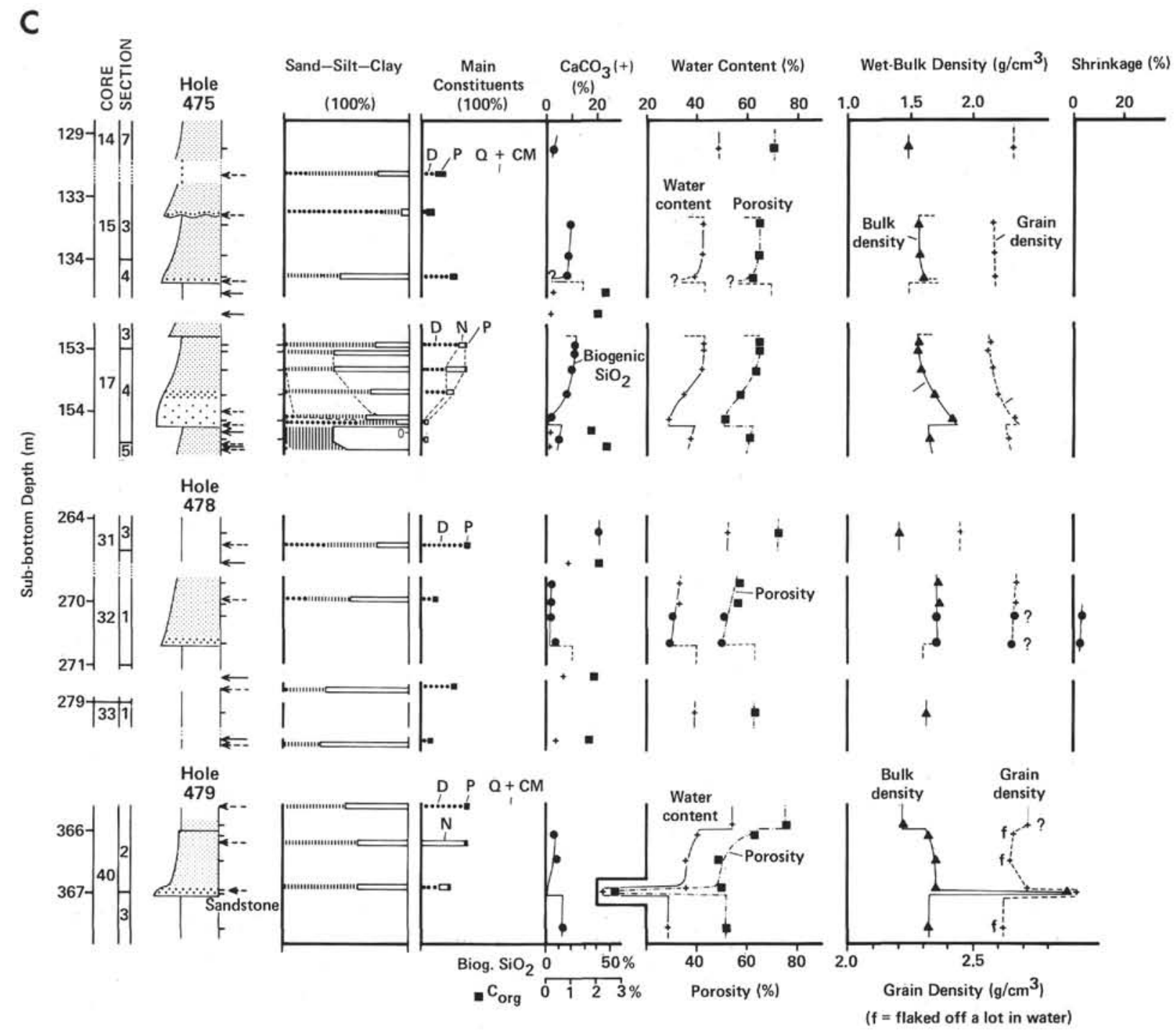

Figure 5. (Continued).

none were encountered, although we recovered the same interval undisturbed at the Guaymas Slope Site 480 . Furthermore, we see no evidence within these layers for the microlaminations that might be expected from the probable basinwide anoxia associated with periods of excessive productivity. Surprisingly, however, diatom frustules in these layers are well-preserved, fragile, upwelling species (e.g., Chaetoceros).

In order to test our suspicion that these oozes were also redeposited, we ran three settling experiments using hemipelagic, muddy, diatomaceous ooze from host sediment from Holes 480 and 478 and the uppermost soft oozes of HPC test Hole 477B. The central body of a terrigenous mud turbidite provided a control sample. Two grams each of sediment were dispersed ultrasonically and allowed to settle in artificial seawater for $48 \mathrm{hr}$. in $30-\mathrm{cm}$ cylinders. With careful syringe extraction, a few milligrams of the surface layer were analyzed by a HIACE automatic particle analyzer (at ETH, Zürich), which measures particle volume by a calibrated light beam. Control smear slides were also prepared. The results showed that the light-colored surface scum on sediment in the settling tube ranged in size from 6-12 $\mu \mathrm{m}$ and consisted mainly of diatom frustules and fragments. The clay size fraction apparently has a slightly greater hydraulic equivalence or else quickly forms flocs in the seawater solution. In contrast, the control sample showed a well-defined peak, less than $2 \mu \mathrm{m}$, from the surface scum. Although the evidence is inconclusive, we infer from this experiment that the mode of transport for such diatom-rich mud turbidites (Type I) may be thick, sluggish, low-concentration turbidity flows which allow a large degree of differential settling. As a consequence, such beds are likely to show effects of differential species sorting beyond the obvious concentration of benthic foraminifers at their base. Diatom frustule concentration increases upward and nannofossils with about $10 \mu \mathrm{m}$ size, but $2.72 \mathrm{~g} / \mathrm{cm}^{2}$ density are concentrated in the middle portions of beds (as seen in the physical properties plots, Fig. 5, later). 
A

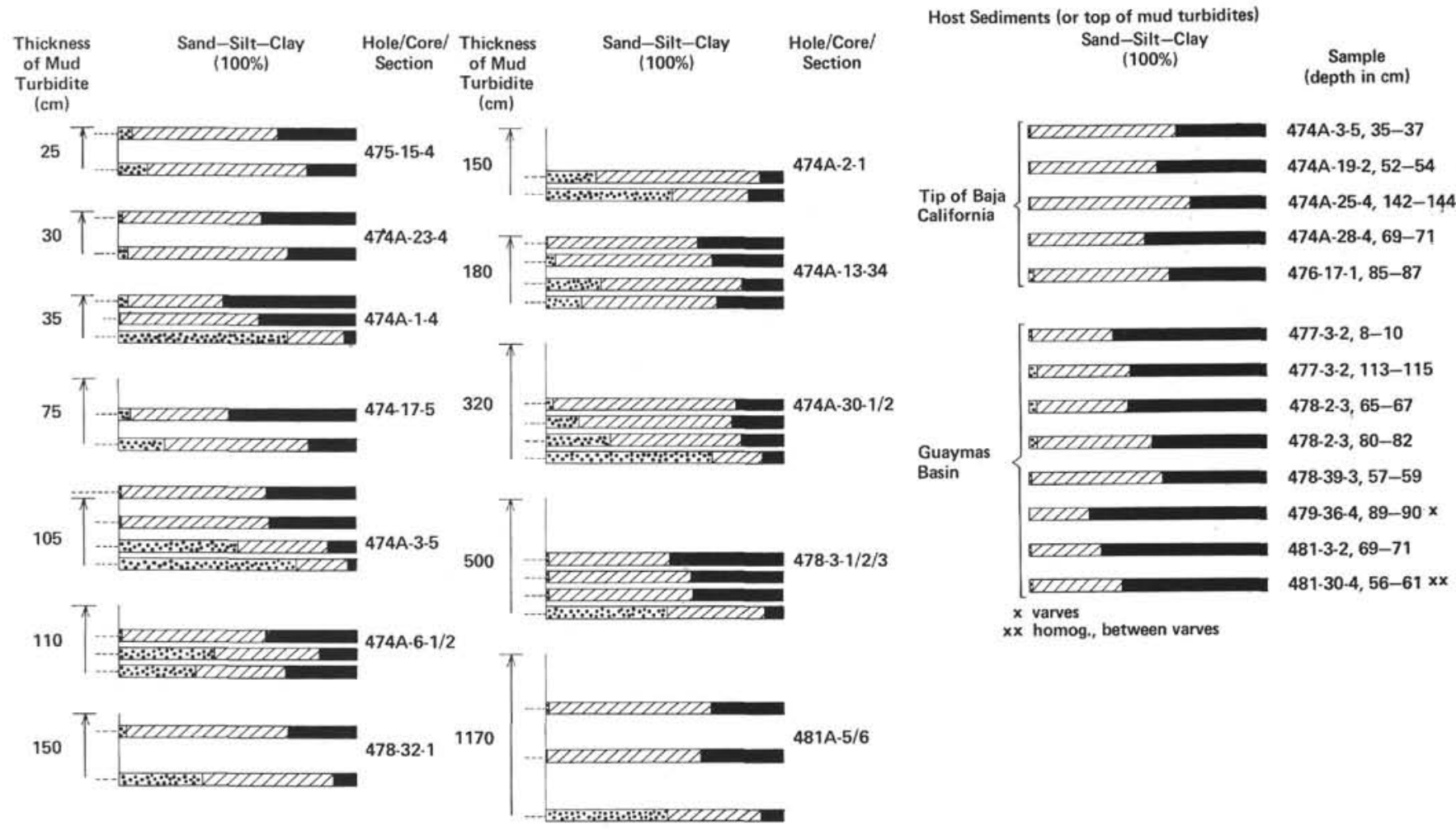

Figure 6. Summary of sand-silt-clay fraction data from Gutierrez-Estrada (this volume, Pt. 2) for (A) specific turbidite beds in order of increasing bed thickness and (B) pelite tops or host sediment. (Dotted lines indicate position of sample in section.)

\section{PHYSICAL PROPERTIES}

\section{Mass Physical Properties of Selected Unconsolidated Mud Turbidites}

Calm seas, a generally low bulk density, and low shear strengths in muds from the Guaymas Basin provided ideal conditions for the HPC tool to penetrate sediments without causing artificial compaction. The high degree of confidence for measurements of water content, wet-bulk density, porosity, shear strength, and shrinkage, particularly for HPC Site 481, allows us to use physical parameters in differentiating mud turbidites from host muds. As mentioned, even seemingly homogeneous redeposits commonly show some gradational aspects (Fig. 2). Turbidite beds buried only 10 to 50 meters sub-bottom, for example, have porosities 10 $20 \%$ lower than the values of $80-90 \%$ of the host sediment. Bulk density exceeds that of the host muds (1.2$1.3 \mathrm{~g} / \mathrm{cm}^{3}$ ) by $0.2-0.4 \mathrm{~g} / \mathrm{cm}^{3}$ (Figs. 2 and 5). Aspects of gradational change within mud turbidites are easily recognized in water content or GRAPE profiles (Fig. 8).

At greater sub-bottom depths, in this case around 130 to 370 meters, the difference in the physical parameters of host and turbidite mud is less pronounced because sediments are compacted. Porosities differ by less than $10 \%$ and bulk density contrasts are less than 0.1 to 0.2 $\mathrm{g} / \mathrm{cm}^{3}$ of the general range of $1.5-1.6 \mathrm{~g} / \mathrm{cm}^{3}$. At these levels, however, macroscopically visible grading characteristics are enhanced.

Because compositional grading is commonly a reflection of increasing opaline silica content nearer the top of a bed, the average grain densities can be calculated as a measure of diatom frustule content (see site chapter for Site 474 , this volume, Pt. 1). We applied this method as a semiquantitative check of smear slide estimates in Figure 5A-D.

Keller and Lambert (1972) recorded higher strength in sandy turbidites than in the intercalated sapropelic muds of the Mediterranean Sea sediments. Although we had only a limited number of shear strength measurements for comparison, these show that mud turbidites have less strength than the host muds in the Guaymas Basin. This is probably caused by a higher silt fraction in turbidites and by concomitant loss of cohesion. Shrinkage increases just near the top of some beds, reflecting increasing clay content.

\section{Lithification of Turbidites}

We noted several instances of partial lithification, most commonly along the basal parts of turbidites (e.g., Fig. 4A). These zones may act as conduits for pore fluids and therefore be more prone to incipient carbonate or opal diagenesis. At Site 474, with heat flow less than $4 \mathrm{HFU}$, the first indurated, coarse sands were encountered at 500 meters sub-bottom. Clayey siltstone at the same depth is weakly indurated, with porosities of $45 \%$ and shear strength values higher than $2 \times 10^{5} \mathrm{~Pa}$ $\left(=2 \mathrm{~kg} / \mathrm{cm}^{2}\right)$. In the Guaymas Basin, some sands were cemented at 60 to 200 meters sub-bottom, whereas surrounding mudstones show porosities of $55-75 \%$ and low cohesion (less than $1 \times 10^{5} \mathrm{~Pa}=1 \mathrm{~kg} / \mathrm{cm}^{2}$ ). Cementation, in these instances, is a direct and indirect con- 


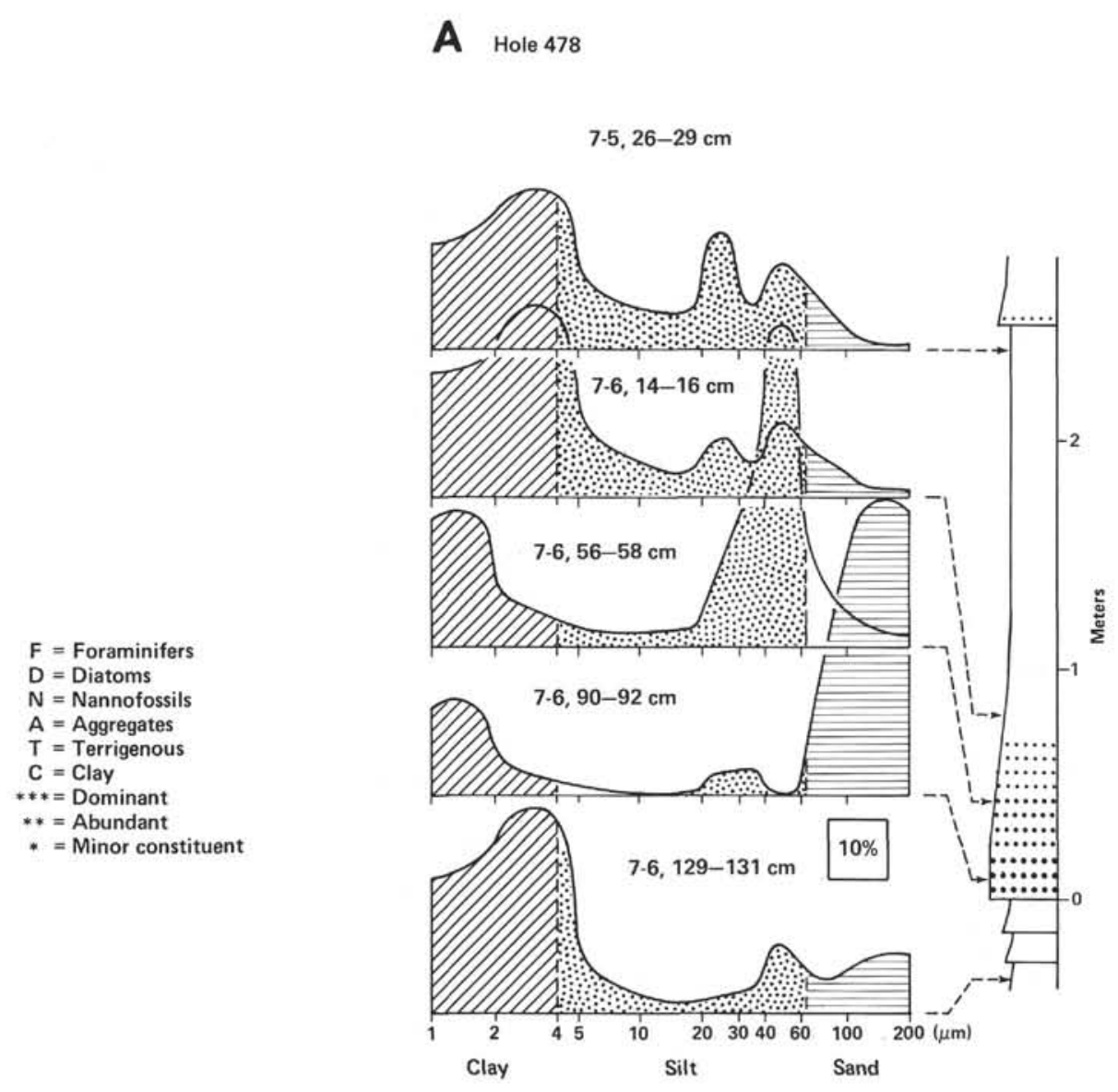

B Hole 478

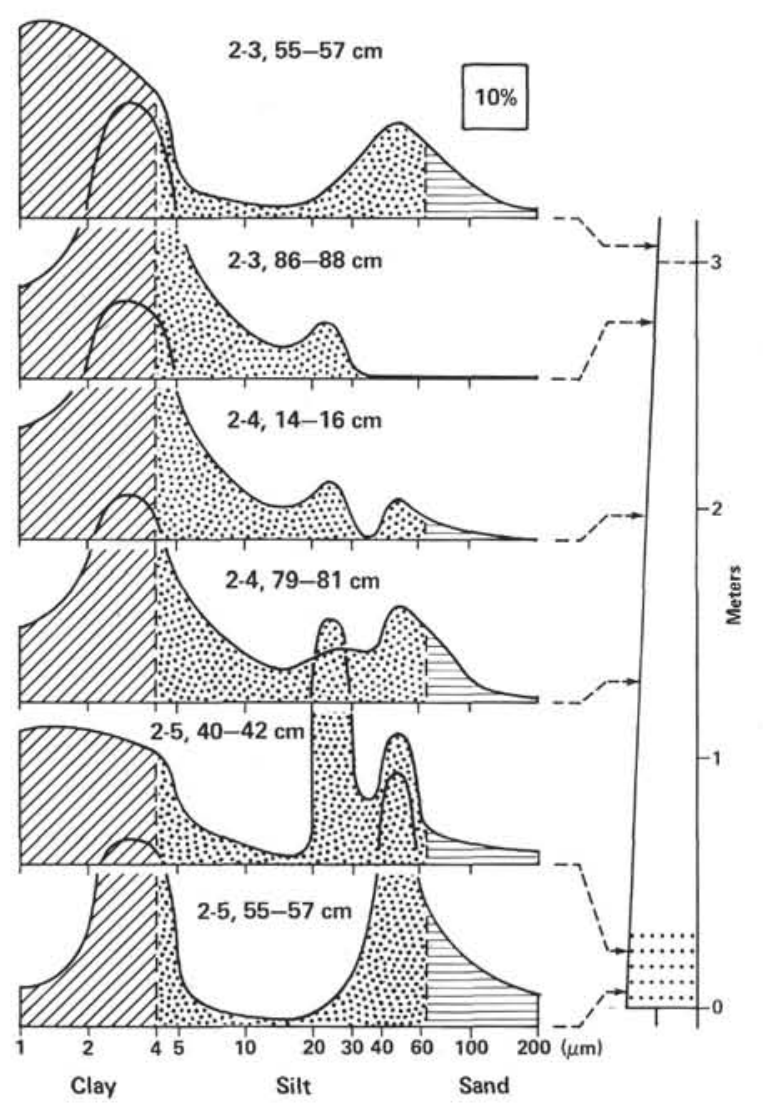


C Hole 481
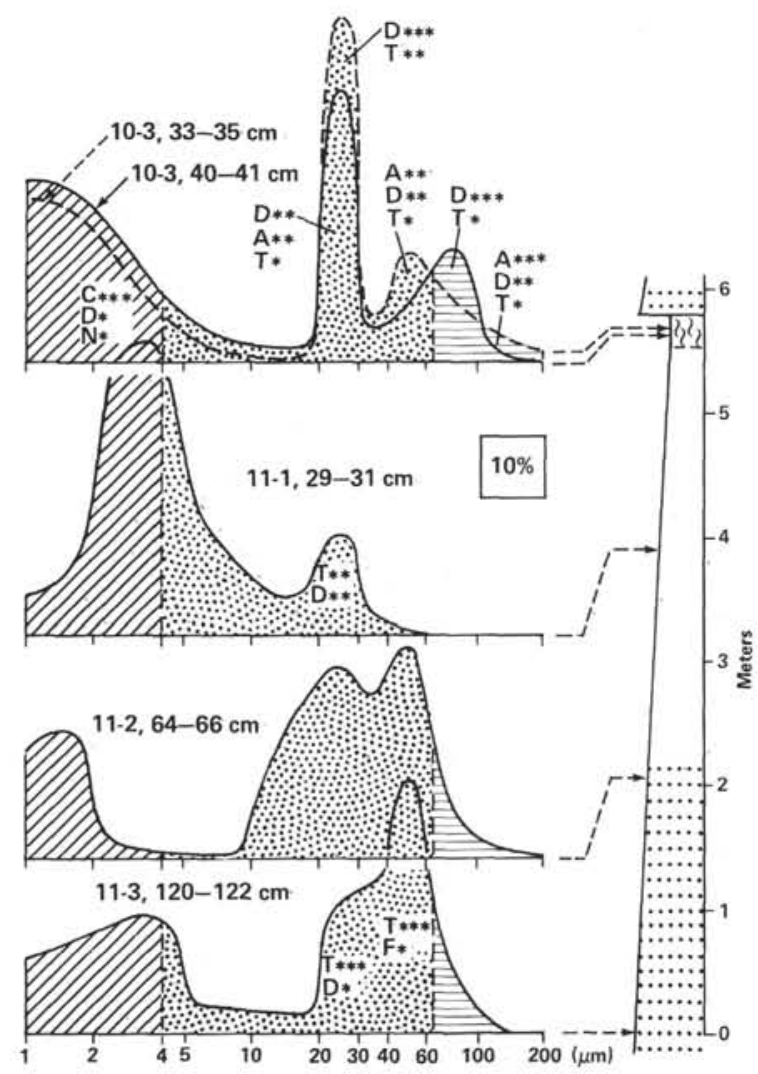

Clay
D

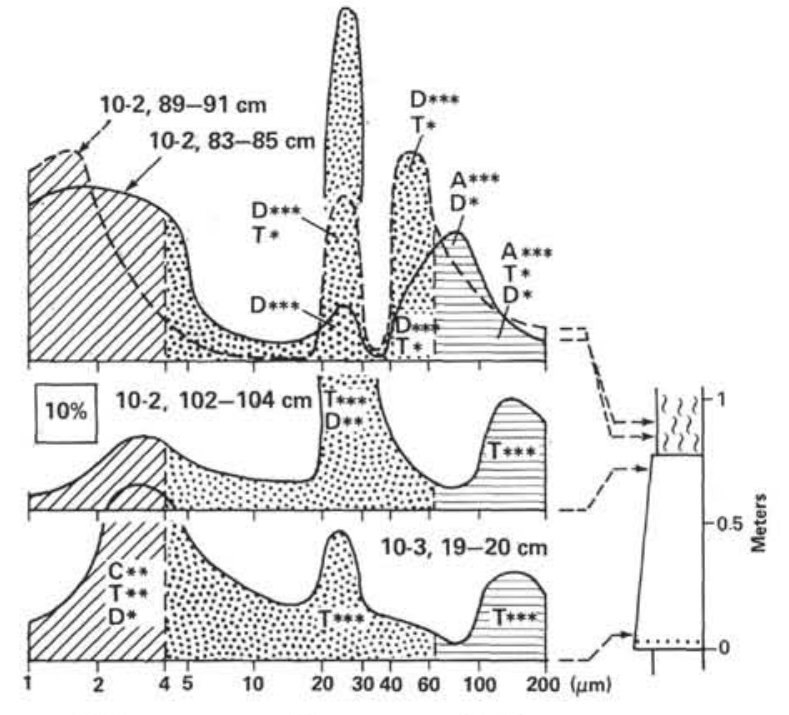

E Hole 481

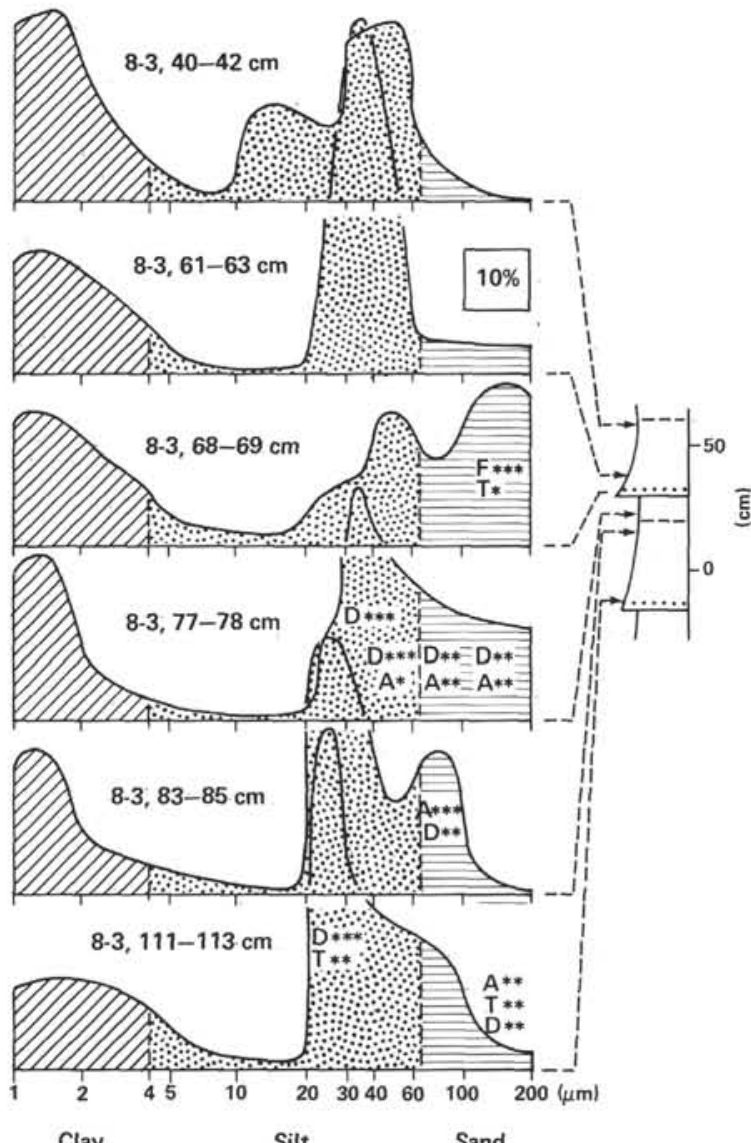

Clay

Silt

Sand

Figure 7. Grain size frequency distribution from samples from different positions in selected mud turbidites as analyzed by ultrasonic sieving (sieve sizes 5 , $10,20,30,40,60$, and $100 \mu \mathrm{m}$ and a filter membrane of $2 \mu \mathrm{m}$ ). A, B. Thick mud turbidites from Site 478, including some host sediment. Note shift in grain size modes in sand and silt fraction from bottom to top. C, D, E. Mud turbidites from Hole 481, Guaymas Basin. Major components are indicated on graphs. Note that textural grading is poorly developed in beds with high proportions of frustules and aggregates (E, lower bed) but well displayed in silty beds with a high percentage of terrigenous material (C). The high sand content of the host sediment is mainly due to frustules and aggregates. 


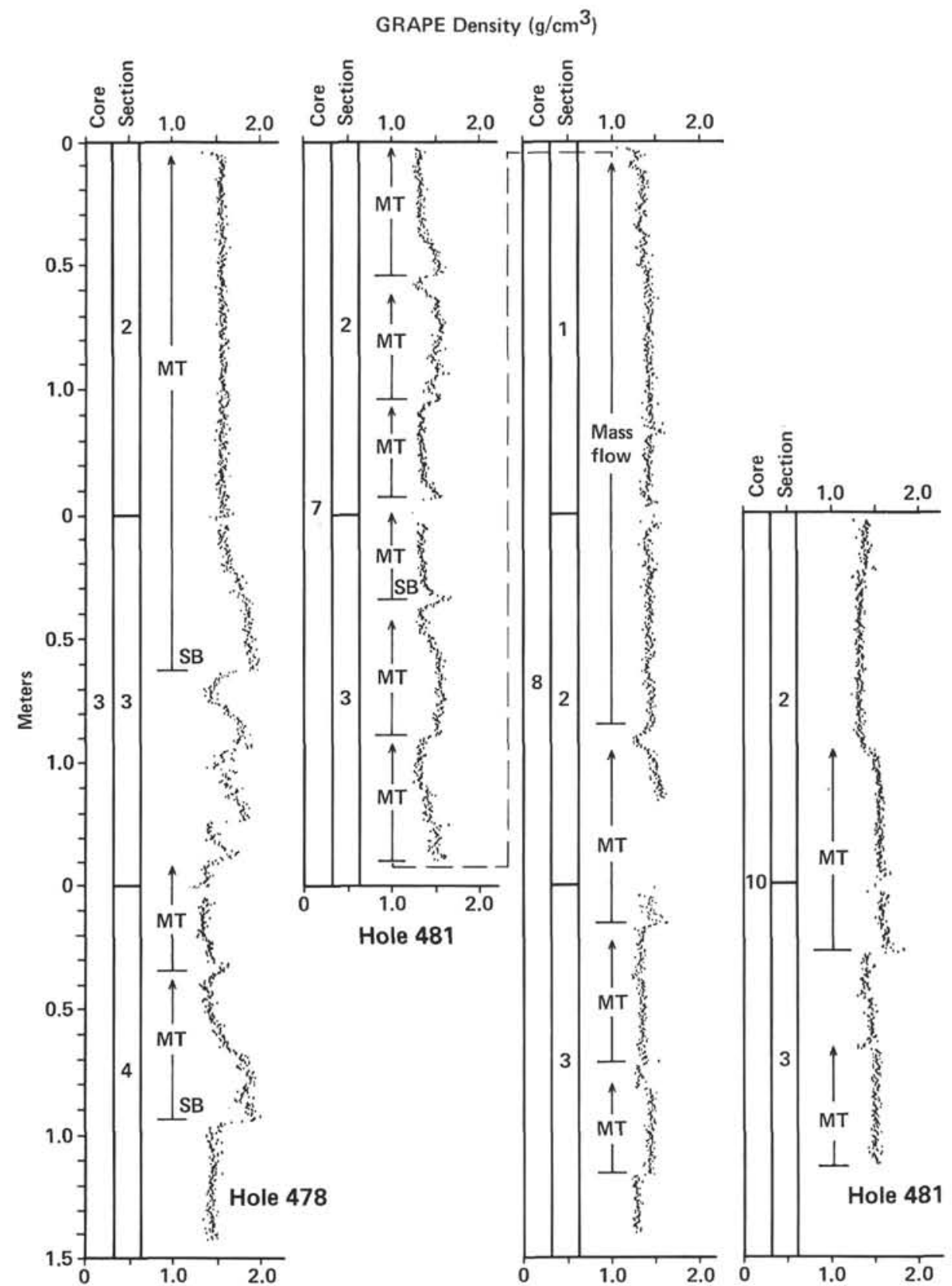

Figure 8. Wet-bulk density profiles of selected undisturbed core sections from the Guaymas Basin as determined by continuous GRAPE measurements. Mud turbidites (MT) show characteristic density grading and a sandy base (SB). A 2.5-meter thick mass flow unit has relatively uniform values with some grading near the top. Host sediment has lower overall values than the body of diatom-rich turbidites.

sequence of the effect of basaltic intrusions and high heat flow $(20 \mathrm{HFU})$ upon soft sediment (see Einsele et al., 1980). Biogenic silica has been considerably transformed in such beds. Logging results and drill recovery confirm the presence downhole of lithologies of varying hardness.

\section{CONCLUSIONS}

\section{Source of Mass Flows and Mud Turbidites}

The composition and distribution of components suggest that most mud turbidites we observed were generated in metastable upper-slope or outer-slope regions and at bathyal depths rather than on shelf areas. Rugged subaqueous topography and tectonic activity in the Gulf (Rusnak et al., 1964; van Andel, 1964) provide ideal settings with broad, gentle, apron regions and some steep slopes including scarps greater than $5^{\circ}$. These collect, store, and then slough off large quantities of the hemipelagic blanket which are redeposited in basin plain areas. A rough estimate of the proportional areas of source and sink depositional sites in the Gulf indicates $28 \%$ continental shelves; $58 \%$ slope regions; and $14 \%$ basin plains with less than $0.3^{\circ}$. Evidence of episodic re- 
moval of hemipelagic sediment along slopes is seen on seismic profiles (e.g., Moore, 1973; Lonsdale and Lawver, 1980) that show steep scarps of truncated sediment and low-angle unconformities. It is probable that a proportionate amount of the basin fill is redeposited from surrounding slopes and aprons and derived from the clastic input along the major fan and delta systems. Both the core analysis and the comparison of laminae thickness between basin and slope indicate $60-75 \%$ redeposits.

Travel distances for turbidity currents in the Guaymas Basin are relatively short compared with examples discussed by Piper (1978). Maximum distances are only $50 \mathrm{~km}$ from the shelf for the perimeter basin Site 474 and $30-80 \mathrm{~km}$ in the Guaymas Basin. In addition, the lack of shallow-water components and of habitat for benthic faunas is further evidence that much of the redeposited mud derived from initially bathyal depths. Relatively poor grading characteristics are a result of the source materials available, the hydraulic equivalence of various components, and the tendency for fine clay to flocculate. Flocs are poorly dissipated if flows decelerate rapidly (Piper, 1978).

Another feature which is probably important in this region is the occurrence of multiple flows and interference patterns. During earthquakes, we can expect slump-generated mass flows to be initiated at several loci simultaneously. These may interfere with one another within the deep rifts, with the densest underflowing others. The currents depositing mud turbidites are probably large, sluggish, low-concentration clouds, possibly with a higher-density flow-separation at the base. Although some authors commonly consider deposition from muddy turbidity currents along only very gentle slopes (Piper, 1978), others (van Andel and Komar, 1969, for example) discuss other decelerating factors that allow thick muds to settle out in basins after ponding. The head of a muddy current fills the basin, and a tail section may be deflected several times before suspended fine sediment settles over a broad area (Hsü and Kelts, 1980). This mechanism can lead to the formation (already noted) of pale olive diatom-rich layers on top of several mud turbidite beds as part of a last-phase nepheloid transport (Malouta et al., 1981). Several small graded or laminated beds may thus derive from the same event.

In terms of the Bouma-Piper classification, Figure 9 schematically summarizes types of turbidite beds identified in cores from Leg 64. The most common are thick, faintly graded turbiditic mud Types 4 and 5 . This pattern is also common in other tectonically active and topographically restricted marginal basins such as the California Borderlands (Malouta et al., 1981) or Hellenic Trench areas (Stanley and Maldonado, 1981). The frequency of sandy beds in the Guaymas Basin series could, for example, be related to denudation of the Yaqui Delta during times of lowered sea level, although we cannot evaluate this possibility with the data available (Malouta et al., 1981).

Stanley and Maldonado (1981) outline an ambiguous interplay of mechanisms for deposition of fine-grained muds. Their model, which treats facies changes from slope-basin to trench-floor environments, interprets depositional mechanisms for turbiditic muds in terms of the progressively decreasing competence of a flow generated by slumps and debris flows. Fine-grained mud is distributed on the trench floor by low-concentration flows or a turbid layer. Malouta et al. (1981) consider hemipelagic mud to be derived predominantly from slope aprons and redistributed laterally by circulating currents and a nepheloid layer.

Very thick, gray, sandy muds, such as the bed in Cores 480-10 and 480-11, are traced to a source area on the Delta of the Yaqui River system some $90 \mathrm{~km}$ away. The thickness of these beds suggests very large trigger events. Rather poor sorting indicates possible transport by low-viscosity mud flows, or at least higher-concentration turbidity currents than diatom-rich beds suggest. The oblique rift setting provides a deep channel which may have confined such flows. These would probably have spilled over and rebounded along opposing slopes.

Because there are two end-member sources of sediment for turbidity currents in the Guaymas Basin, a continuum of bed types and compositions is possible. Silt content cannot be used as a reliable indicator of proximal-distal relationships nor as evidence of any position within a submarine fan complex (Piper, 1978). Although steep fans occur in the basin, it appears that many currents bypass these and spread out over the whole basin plain. However, coring would be necessary to establish the geometry of even the largest mass flow bodies.

\section{The Contribution of Mud Turbidites to Total Sediment Volume}

Although our examination is limited to parts of a few holes, we conclude that mud turbidites contribute greatly to the basinal hemipelagic sediments of the Gulf region. Quantitative estimates are hampered by drill disturbance and bioturbation in the many thin beds. Nevertheless, we estimate that for the perimeter basin of Site 474 along the tip of Baja California, $75 \%$ of the section on young oceanic crust consists of mud turbidites. In the Guaymas Basin, mud turbidites form at least $60 \%$ of the total sediment. Even in the outer slope basins of Sites 475 and $476,10-20 \%$ of the undisturbed sediment consists of mud turbidites. However, along the Guaymas Basin slope, Sites 480 and 479 , redeposits were rarely encountered.

Beds vary greatly in thickness, describing a roughly log-normal pattern (Fig. 10). In both basinal areas the mode is $25-50 \mathrm{~cm}$, but whereas mud turbidite beds of the southern perimeter basin show a symmetrical distribution, those of the Guaymas Basin are skewed positive. This pattern is even more pronounced for a plot of the fractional contribution of each turbidite bed to the total turbidite package (Fig. 9, curve b). In the perimeter basin, $19 \%$ of turbidite thickness is accounted for by beds $100-141 \mathrm{~cm}$ thick. In the Guaymas Basin, 8 single mud turbidite beds between 200 and $283 \mathrm{~cm}$ contribute $14 \%$ of the total thickness of turbidites. This pattern is probably a reflection of the existence of the large muddy 


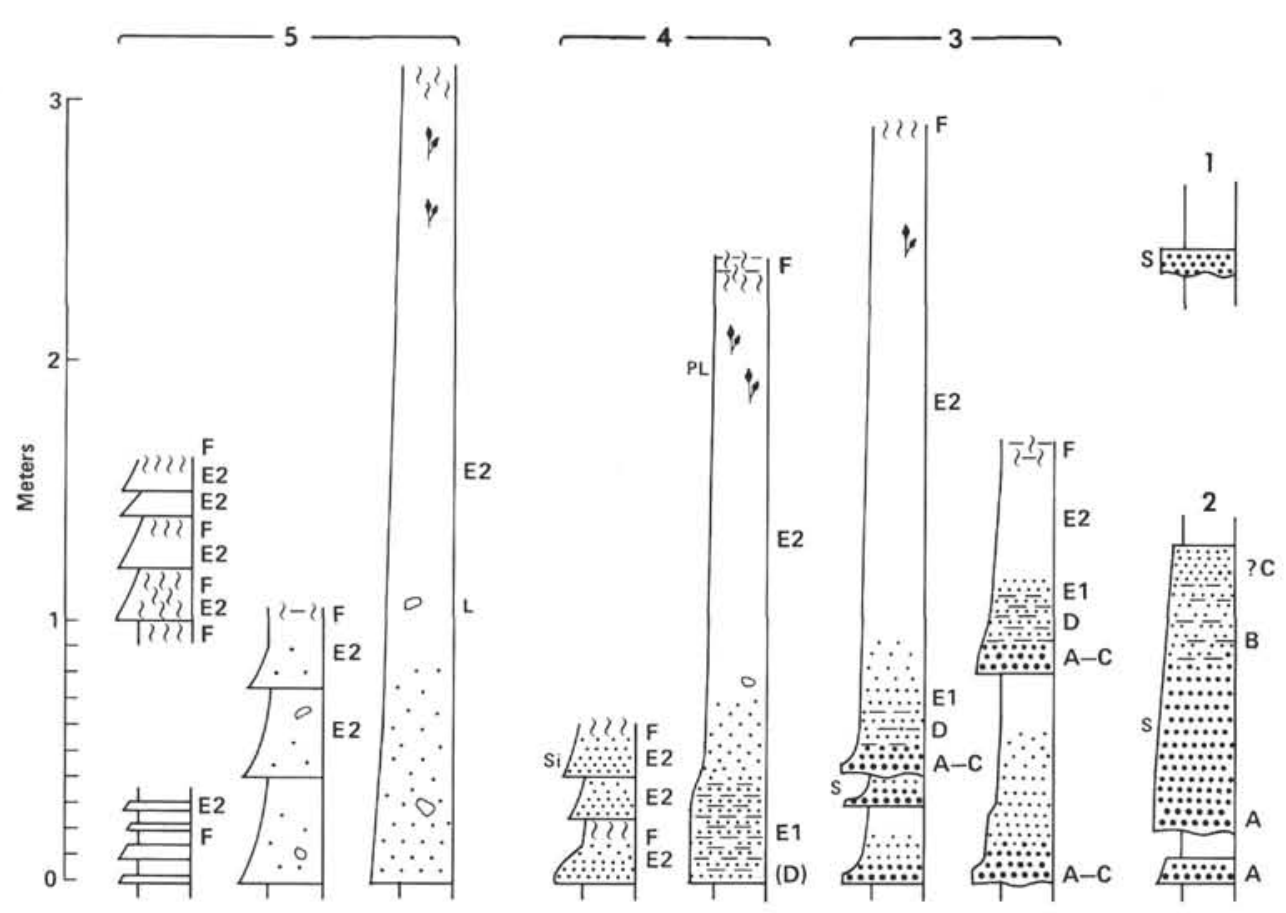

Figure 9. Schematic summary of various bed types encountered in cores from the Gulf of California. Classification of sedimentary structures follows Bouma Units A to F (Bouma, 1962), with modifications by Piper (1978) for mud turbidite Units E-1 to E-3. Types are organized by decreasing sand content: 1 . Thin, well-sorted sands with sharp contacts from slope settings. 2 . Sandy graded beds. 3 . Thin basal graded sand layer with massive silt body. 4 . Thick beds with poorly sorted silty-sand base, faint parallel laminations and a massive clayey-silt body. 5. Thick or thin, graded (E-2) mud turbidites. Types C to E are most common. Symbols are S, sand; Si, silt, B, burrows; PL, plant debris; L, mud lump clasts.

delta of the Yaqui River system and the consequent possibilities for large mass flows generated by sporadic jolts along transform faults.

We observed one large, dominantly sandy mass flow in Hole 474 (Moore et al., this volume, Pt. 2) and two muddy mass flows in Hole 481A distinguished by wellpreserved convolute folds and density grading seen on logs (see Site 481 site chapter, this volume, Pt. 1). The Hole 481A mud flows are 10 and 31 meters thick and thus form $14 \%$ of the sediment column. Identification and recovery were possible only because of the slight induration caused by the effects of sill intrusions (Einsele et al., 1980). The composition and preservation of delicate sedimentary fold structures and undigested chunks of mud with laminated couplets imply that these beds slumped locally from the inner rift wall. We must assume, therefore, that in other holes and parts of the Guaymas Basin similar mass flows are also present, although unrecognized because of core disturbance and recovery.

\section{Frequency of Turbidite Events}

The frequency of turbidite events is difficult to estimate and possibly a trivial exercise, because time control is poor and it is likely that one earthquake in this region will dislodge mass flows simultaneously in several areas. Thus a sequence of beds can derive from the same event. In another small ocean, the Algéro-Balearic Basin of the Western Mediterranean, Rupke and Stanley
(1974) used radiocarbon ages to determine a frequency of 3 events/ky. over the last $20 \mathrm{ky}$. This high frequency is mainly a consequence of their recognition of mud turbidites. We found 249 beds at Site 474 with $57 \%$ core recovery. If we assume equivalent facies in missing sections, then there is an apparent frequency of 1 event $/ 8$ ky. In the Guaymas Basin, the exercise is even more speculative, but we counted 100 events for $73 \%$ recovery in Hole 478, which is 320 meters deep. The estimated nannofossil age of $300 \mathrm{ky}$. (see site chapter, this volume, Pt. 1), gives approximately $2 \mathrm{ky}$. per event. A similar estimate was calculated for Site 481, with 63 mud turbidites in the $58 \%$ recovery of the 330 -meter section. Despite gross uncertainties, these figures suggest a significantly higher frequency of events in the Guaymas Basin than in the perimeter basin, with at least the same order of magnitude as in the small Alboran Basin. This estimate is probably low. Malouta et al. (1981), in their study of young sediments of the Borderland basins, estimate a frequency of up to 1 event/200 y.

\section{Mass Physical Properties}

The alternation of redeposited and host sediment produces a sequence of diverse, episodic changes in the initial physical property patterns that affect the sediments in various ways. Poorly permeable, fine-grained host layers divert pore water escape-flow along turbidite layers (e.g., Magara, 1978). In basins characterized by high accumulation rates, abnormal pore pressures are 

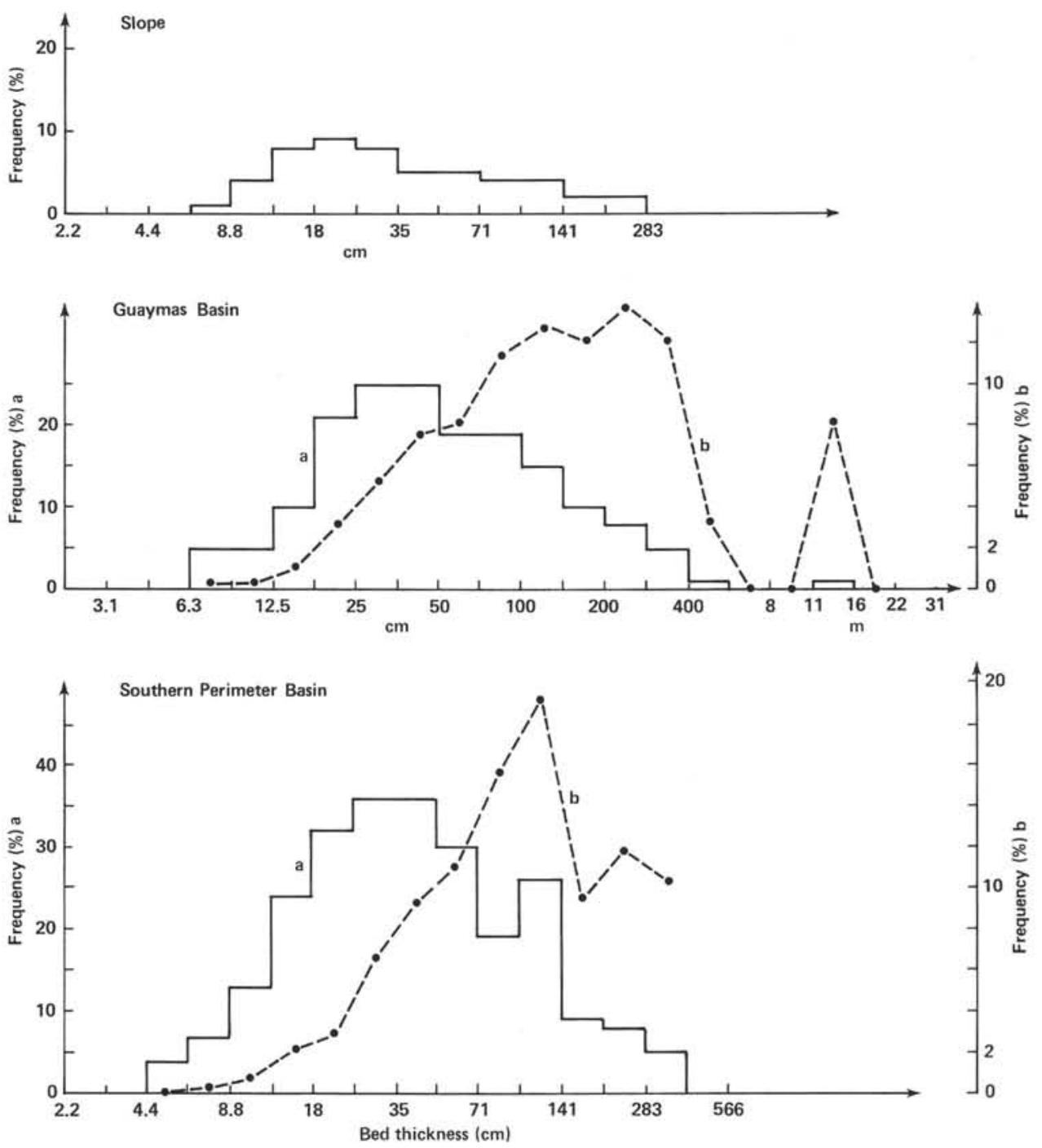

Figure 10. Histograms (curve a) showing relative frequency of various turbidite bed thicknesses in different settings: slope, Guaymas Basin plain, and southern perimeter basin Site 474. For the basins, the scale on the right-hand margin for curve b show the relative importance of each thickness group to the total turbidite package.

likely to be generated at some depth. This is accentuated by pore-water expulsion processes in conjunction with the multiple intrusions of basaltic sills. Migrating pore waters or hydrothermal fluids move along more porouspermeable layers until encountering a convenient exit along fault intersections (Einsele et al., 1980). Silty muds in the main body of a turbidite can still have higher permeabilities-although lower porosities-than host muds, as Archie (1950) noted.

Our measurements of bulk density with up to 0.3 $\mathrm{g} / \mathrm{cm}^{3}$ difference between host and redeposited muds also confirm postulates (for instance Dzulynski and Walton, 1965) that load casts at the base of sandy turbidites were caused by marked differences in bulk densities and formed soon after deposition. In moderate slope areas, the presence of turbidite layers has counterbalancing effects. Lower shear strength and loading may add to instabilities, but the higher permeabilities may help drain off pore water that has been expelled by early compaction.

\section{Structural Setting}

Many orogenic belts contain massive sequences of muddy hemipelagic sediment. Our description of details of the mud turbidite fill in the Gulf of California can therefore provide a useful case study on which to base some comparative paleoenvironmental reconstructions (e.g., Kelts, 1981). The rate of lateral movement of the Baja Peninsula relative to Mexico is about twice as fast $(6 \mathrm{~cm} / \mathrm{y}$.) as the rate of extension perpendicular to the Gulf axis. This oblique rifting has created the string of small basins along a zone of young ocean crust that has been formed in a complex fashion. The amounts of lateral versus extensional movement in this system may not be identical to that in many ancient ocean basins, but even the present-day African rift system, the Red Sea graben, and Gulf of Aden all show evidence of strikeslip movement. Such differential and tectonically active translational margins are bound to collect a large volume of redeposited muddy sediment (Einsele and Nie- 
mitz, this volume, Pt. 2), in hemipelagic settings, along complex slopes, aprons, slope basins, and basin plains.

\section{ACKNOWLEDGMENTS}

We appreciate discussions and help from our shipboard colleagues as well as the technical assistance of the DSDP production staff. We thank W. Wildi and P. Homewood for reviews of the manuscript.

\section{REFERENCES}

Archie, G. E., 1950. Introduction to petrophysics of reservoir rocks. Bull. Am. Assoc. Pet. Geol., 34:943-961.

Bischoff, J. L., and Henyey, T. L., 1974. Tectonic elements of the central part of the Gulf of California. Geol. Soc. Am. Bull., 85: 1893-1904.

Bischoff, J. L., and Niemitz, J., 1980. Bathymetric Map of the Gulf of California. U.S. Geol. Surv. Misc. Ser. Map 1-1244.

Bouma, A. H., 1962. Sedimentology of Some Flysch Deposits: A Graphic Approach to Facies Interpretation: Amsterdam (Elsevier).

Dzulynski, S., and Walton, E. K., 1965. Sedimentary Features of Flysch and Greywackes: Amsterdam (Elsevier).

Einsele, G., Gieskes, J. M., Curray, J. R., Moore, D. M., Aguayo, E., Aubry, M.-P., Fornari, D., Guerrero, J., Kastner, M., Kelts, K., Lyle, M., Matoba, Y., Molina-Cruz, A., Niemitz, J., Rueda, J., Saunders, A., Schrader, H., Simoneit, B., and Vacquier, V., 1980. Intrusion of basaltic sills into highly porous sediments, and resulting hydrothermal activity. Nature, 283:441-445.

Hesse, R., 1975. Turbiditic and nonturbiditic mudstone of Cretaceous flysch sections of the East Alps and other basins. Sedimentology, 22:387-416.

Hsü, K. J., Kelts, K., and Valentine, J., 1980. Resedimented facies in Ventura Basin and a model of longitudinal transport of turbidity currents. Bull. Am. Assoc. Pet. Geol., 64:1034-1051.

Karig, D. E., and Jensky, W., 1972. The proto-Gulf of California. Earth Planet. Sci. Lett., 17:169-174.

Keller, G. H., and Lambert, D. N., 1972. Geotechnical properties of submarine sediments, Mediterranean Sea. In Stanley, D. J. (Ed.), The Mediterranean Sea: Stroudsburg (Dowden, Hutchinson, and Ross), pp. 401-415.

Kelts, K., 1981. A comparison of some aspects of the sedimentation and translational tectonics from the Gulf of California and the Mesozoic Tethys, Northern Penninic Margin. Eclog. Geol. Helv., 74:317-338.

Kelts, K., and Arthur, M. A., 1981. Turbidites after ten years of Deep Sea Drilling-wringing out the mop. In Warme, J. B., Douglas, R. G., Winterer, E. L. (Eds.), The Deep Sea Drilling Project: A Decade of Progress: Soc. Econ. Paleon. Min. Spec. Publ. 32: 91-127.

Lambert, A. M., Kelts, K. R., and Marshall, N. F., 1976. Measurements of density underflows from Walensee, Switzerland. Sedimentology, 23:87-105.

Larson, R. L., Menard, H. W., and Smith, S. M., 1968. Gulf of California: A result of ocean floor spreading and transform faulting. Science, 161:781-784.
Lonsdale, P., and Lawver, L. A., 1980. Immature plate boundary studied with a submersible in the Gulf of California. Geol. Soc. Am. Bull. Pt. I, 91:555-569.

McCave, I. I., 1979. Diagnosis of turbidites at Sites 386 and 387 by particle-counter size analysis of the silt $(2-40 \mu \mathrm{m})$ fraction. In Tucholke, B. E., Vogt, P. R., et al., Init. Repts. DSDP, 43: Washington (U.S. Govt. Printing Office), 395-405.

Magara, K., 1978. Compaction and Fluid Migration-Practical Petroleum Geology: Amsterdam (Elsevier).

Malouta, D. N., Gorsline, D. S., and Thornten, S. E., 1981. Processes and rates of recent (Holocene) basin filling in an active transform margin: Santa Monica Basin, California continental Borderland. J. Sed. Petrol., 51:1077-1096.

Moore, D. G., 1973. Plate-edge deformation and crustal growth, Gulf of California structural province. Geol. Soc. Am. Bull., 84: 1883-1906.

Moore, D. G., and Buffington, E. C., 1968. Transform faulting and growth of the Gulf of California since the late Pliocene. Science, 161:1238-1241.

Pilkey, O. H., Locker, S. D., and Cleary, W. J., 1980. Comparison of sand layer geometry on flat floors of 10 modern depositional basins. Bull. Am. Assoc. Pet. Geol., 64:841-856.

Piper, D. J. W., 1978. Turbidite muds and silts on deepsea fans and abyssal plains. In Stanley, D. J., and Kelling, G. (Eds.), Sedimentation in Submarine Canyons, Fans, and Trenches: Stroudsburg (Dowden, Hutchinson, and Ross), pp. 163-176.

Ricci-Lucchi, F., and Valmori, E., 1980. Basin-wide turbidites in Miocene oversupplied deep-sea plain: A geometrical analysis. Sedimentology, 27:241-270.

Rupke, N. A., and Stanley, D. J., 1974. Distinctive Properties of Turbiditic and Hemipelagic Mud Layers in the Algero-Balearic Basin, Western Mediterranean Sea. Smithsonian Contrib. Earth Sci., No. 13.

Rusnak, G. A., Fisher, R. L., and Shepard, F. P., 1964. Bathymetry and faults of Gulf of California. In van Andel, Tj. H., and Shor, G. G., Jr. (Eds.), Marine Geology of the Gulf of California: A Symposium. Am. Ass. Pet. Geol. Memoir 3:59-75.

Stanley, D. J., and Maldonado, A., 1981. Depositional models for fine grained sediment in the western Hellenic Trench, Eastern Mediterranean. Sedimentology, 28:273-290.

Stow, D. A. V., and Bowen, A. J., 1980. A physical model for the transport and sorting of fine-grained sediment by turbidity currents. Sedimentology, 27:31-46.

Thiede, J., 1978. Pelagic sedimentation in immature ocean basins. In Ramberg, I. B., and Neumann, E. R. (Eds.), Tectonics and Geophysics of Continental Rifts: Dordrecht (D. Reidel), pp. 237-248.

Van Andel, Tj. H., 1964. Recent marine sediments of Gulf of California. In Van Andel, Tj. H., and Shor, G. G., Jr. (Eds.), Marine Geology of the Gulf of California: A Symposium. Am. Assoc. Pet. Geol. Memoir 3:216-310.

Van Andel, Tj. H., and Komar, P. D., 1969. Ponded sediments of the mid-Atlantic ridge between $22^{\circ}$ and $23^{\circ}$ north latitude. Geol. Soc. Am. Bull., 80:1163-1190. 

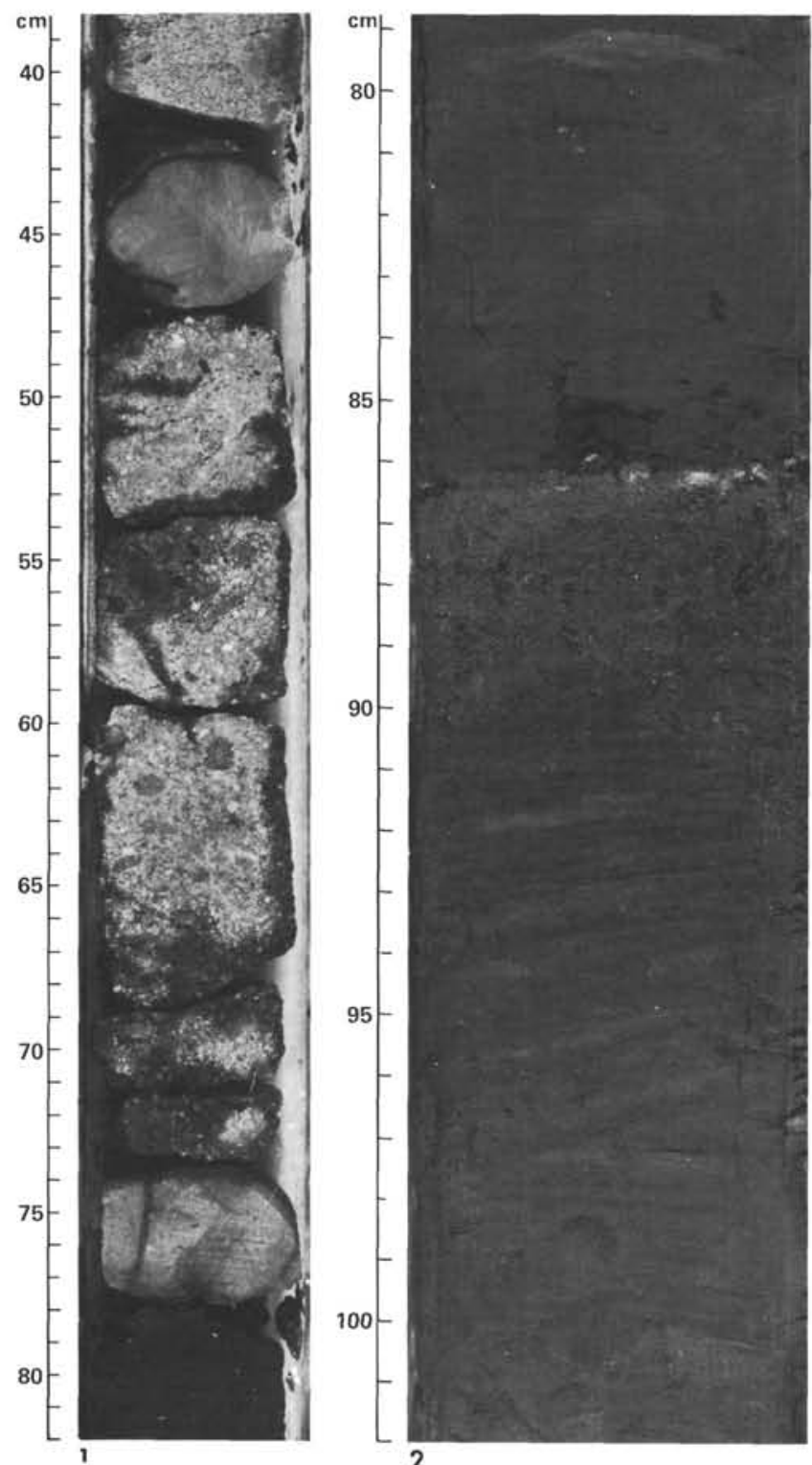

2
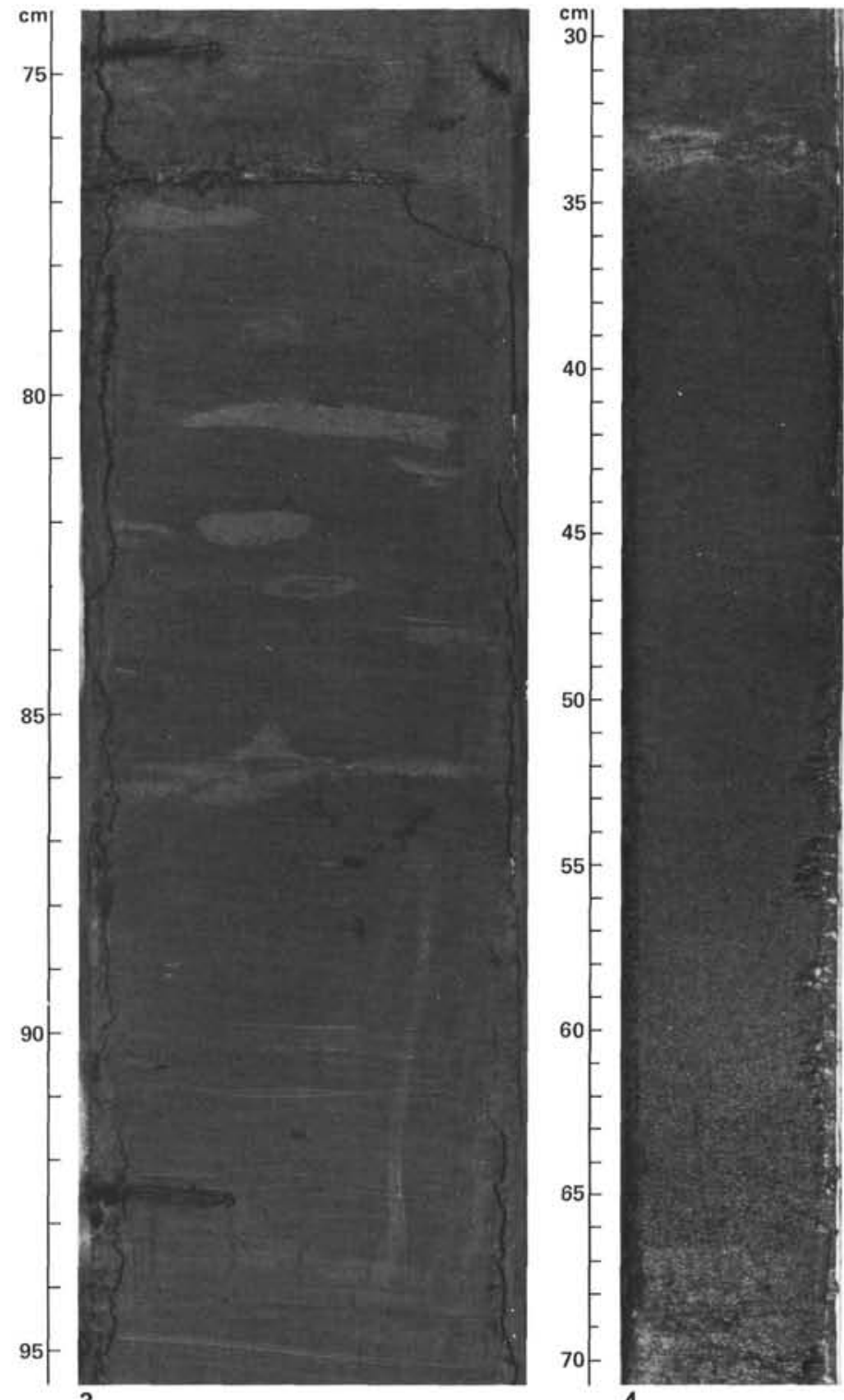

4

Plate 1. Core examples of turbidite layers. 1. Sample 474A-38-1, 40-80 cm, a calcite-cemented, coarse-grained basal part of an arkosic turbidite which is moderately well sorted and faintly graded; occurs at a sill contact and includes some weathered volcanic clasts. 2. Sample 475-15-3, $80-120 \mathrm{~cm}$, thin, basal, graded, silty sand from an outer slope basin; poorly sorted, and top pervasively burrowed; note that the photograph shows streaks from scraping the surface. 3. Sample 474A-13-3, 75-95 cm, faint evidence for a thin, olive brown mud turbidite with thin sand laminae lining the base and faint Chondrites burrows marking the top; body includes some light-colored meniscate and Planolites burrows. 4. Sample 481-8-3, 30-70 cm, biogenic mud turbidite from the Guaymas Basin; massive diatomaceous silty body with poorly sorted graded base, perhaps with a concentration of benthic foraminifers, and a thin, lightly burrowed pale olive top. 

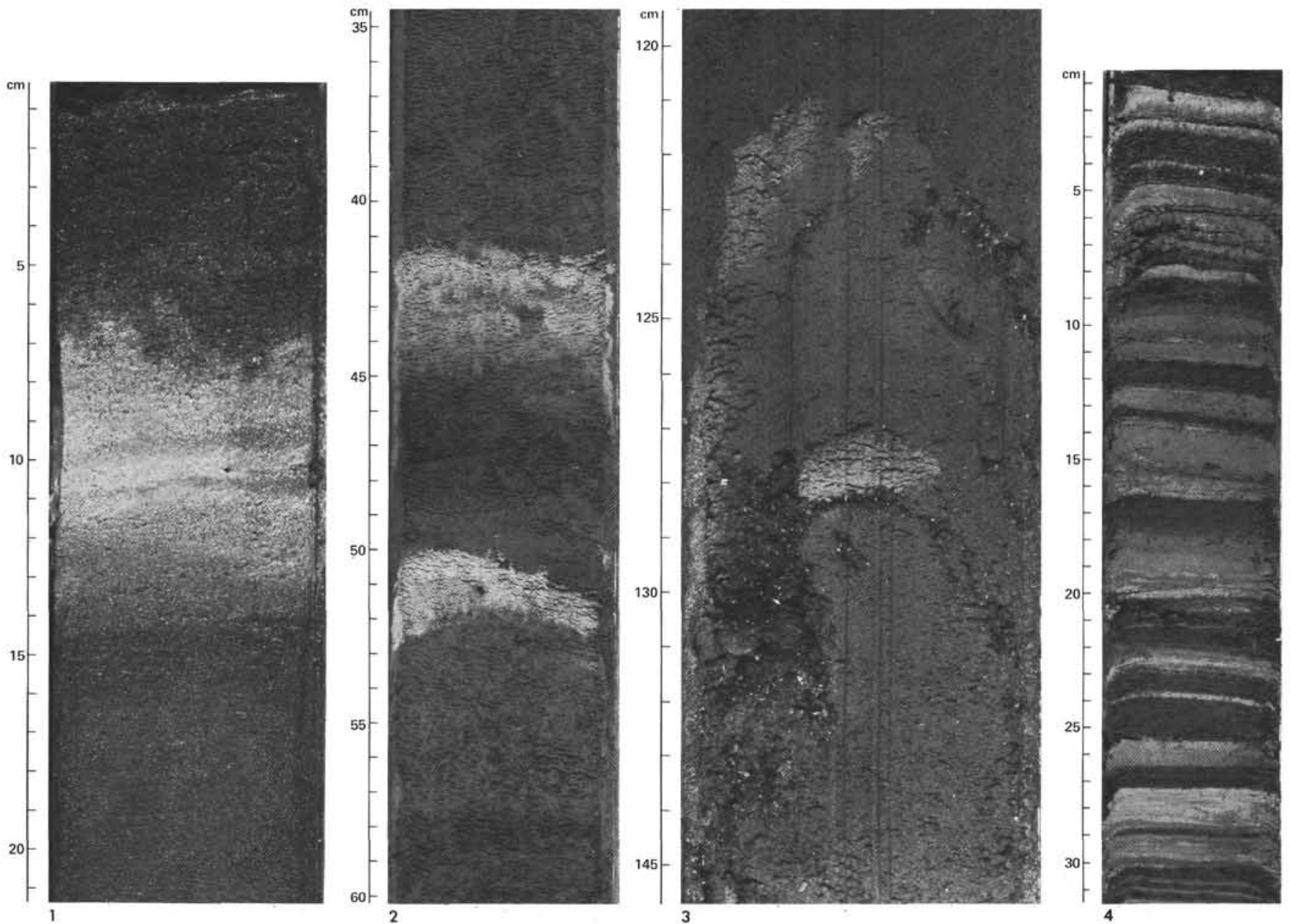

Plate 2. Examples of pale olive diatom-rich layers in dark olive brown muds of the Guaymas Basin plain. 1. 481-2-2, 0-20 cm, thick diatom-rich ooze layer $(0-14 \mathrm{~cm})$ overlying a Type I biogenous mud turbidite. As shown here, the top $6 \mathrm{~cm}$ is dark gray because of pigmentation by unstable iron monosulfides $(5 y$ y $3 / 2)$ whereas the center portion shows a more oxic state of pale olive $(10 \mathrm{y} 6 / 2)$. 2 . Sample $478-11-6,35-60 \mathrm{~cm}$, two cycles of thin beds, each having a pale olive diatom-rich top, gradational to olive drab diatomaceous muds, and a thin basal zone with somewhat sorted fine sand. 3. Sample 478-2-2,120-135 cm, disturbed layers of pale olive diatom ooze in association with very coarse, immature, angular sand grains and shelly hash. Interpreted as redeposits from narrow, steep shelf areas along the Baja Margin. 4. Sample 480-21-2, 0-30 cm, unique series of multiple, thin, terrigenous gray silts and gray sand layers intercalated with diatom ooze from a marginal slope site; undisturbed sediment structures interpreted as current-winnowed current deposits rather than as well-defined graded turbidites. 